Review

\title{
Current Trends in Enrichment of Wheat Pasta: Quality, Nutritional Value and Antioxidant Properties
}

\author{
Dariusz Dziki (D)
}

check for

updates

Citation: Dziki, D. Current Trends in Enrichment of Wheat Pasta: Quality, Nutritional Value and Antioxidant Properties. Processes 2021, 9, 1280. https://doi.org/10.3390/pr9081280

Academic Editor: Bonglee Kim

Received: 27 June 2021

Accepted: 23 July 2021

Published: 25 July 2021

Publisher's Note: MDPI stays neutral with regard to jurisdictional claims in published maps and institutional affiliations.

Copyright: (C) 2021 by the author. Licensee MDPI, Basel, Switzerland. This article is an open access article distributed under the terms and conditions of the Creative Commons Attribution (CC BY) license (https:// creativecommons.org/licenses/by/ $4.0 /)$.
Department of Thermal Technology and Food Process Engineering, University of Life Sciences in Lublin, 31 Głęboka St., 20-612 Lublin, Poland; dariusz.dziki@up.lublin.pl; Tel.: +48-81-445-61-25

\begin{abstract}
Wheat pasta is one of the most important cereal products and is becoming increasingly popular worldwide because of its convenience, simple formulation, long shelf life, and high energetic value. Wheat pasta is usually obtained from refined flour rich in carbohydrates but with low content of phytochemicals, micronutrients, and fibre. The increased demand of consumers for healthy foods has generated interest among both researchers and food producers in developing functional food products. This review showcases the current trends in pasta fortification. Changes in the nutritional value, cooking quality, sensory attributes, and antioxidant properties of durum and common wheat pasta enriched with both plant and animal raw materials are discussed.
\end{abstract}

Keywords: wheat pasta; fortification; nutritional value; quality; antioxidant properties; durum wheat; common wheat

\section{Introduction}

Wheat pasta, after bread, is among the most popular, easy to prepare, and versatile food products. It is a rich source of complex carbohydrates (74-77\%) and protein (11-15\%) and a poor source of sodium, amino acids, and total fat. The best-quality pasta is obtained from durum flour (semolina) [1]. Semolina is produced by milling durum wheat (Triticum durum) with a high level of gluten, which allows a final product with very good quality to be obtained. Moreover, the high content of carotenoids in semolina and the coarse granularity result in pasta with a more attractive yellow colour than common wheat pasta [2]. However, durum wheat constitutes only approximately $5 \%$ of the world's wheat production, and its cost is higher than that of common wheat (Triticum aestivum L.) [3]. Therefore, pasta is frequently produced from common wheat flour.

Most pasta products are obtained from refined flour rich in easily digestible carbohydrates. These products have a low content of fibre and other biologically active compounds such as phenolic acids, flavonoids, and vitamins. A diet rich in these compounds plays an important role in the prevention of cardiovascular diseases, diabetes, and cancer [4,5]. Traditional pasta provides only approximately $5 \%$ of the recommended daily intake of magnesium and zinc [6]. Pasta from wholemeal wheat is highly nutritive but has poor sensory properties [7]. In recent years, there has been a global trend of consumption of cereal products enriched with different plant materials rich in antioxidants, dietary fibre (DF), protein, vitamins, and minerals. Plants are a rich source of many bioactive compounds with antioxidant properties, such as phenolic compounds, vitamins, alkaloids, and other phytochemicals [8,9], which have a positive influence on human health and could decrease the risk of the development of many diseases [10]. Epidemiological studies have strongly indicated that the long-term consumption of foods rich in polyphenols in particular protects against the development of certain types of cancer, diabetes, osteoporosis, and neurodegenerative and cardiovascular diseases [11]. Polyphenols are the most abundant plant secondary metabolites and can be divided into several structural groups: phenolic acids, flavonoids, stilbenes, tannins, and lignans [12]. Foods rich in phenolic acids, flavonoids, and fibre have been shown to exert a positive influence on human health $[11,13]$. 
Enrichment of pasta with plant additives increases the level of phenolic compounds in the prepared product [9]. Moreover, in the last few years, the possibility to incorporate animal raw materials such as fish by-products or insects into pasta has also been widely tested (Figure 1). These materials are a rich source of protein, fat, and fibre [14,15].

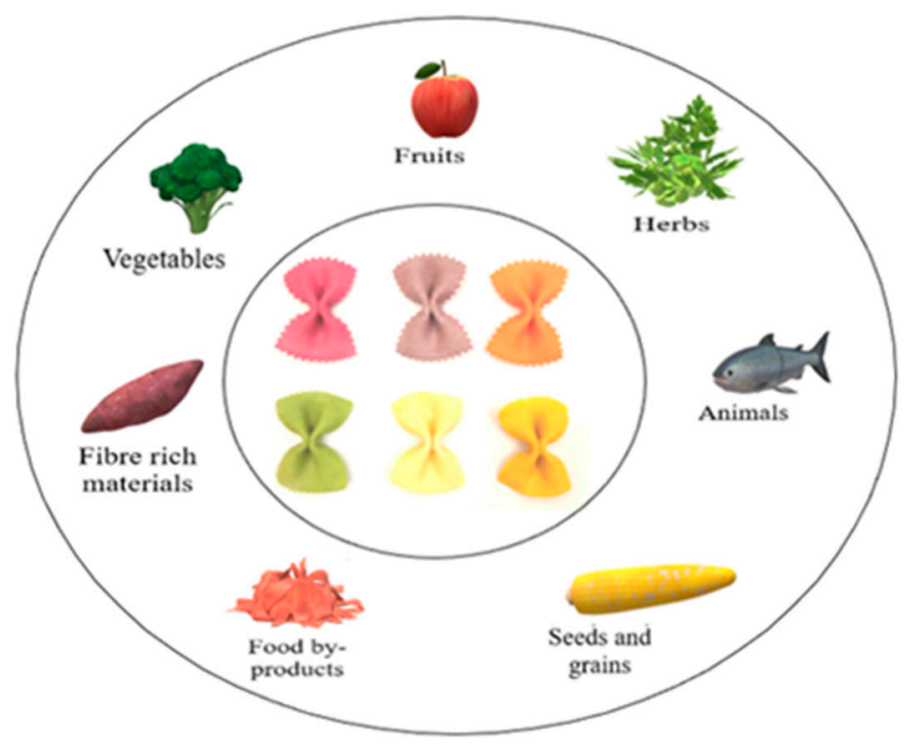

Figure 1. Current trends in pasta enrichment.

Pasta quality is related to its sensory properties, such as texture, colour, appearance, and flavour [16]. The cooking properties of pasta, such as optimal cooking time, weight increase index, swelling properties, and cooking loss, are also important characteristics of this product [14]. Pasta quality depends mainly on the ingredients used for its preparation. The method of production (lamination or extrusion) [17,18], dough mixing process, and drying conditions also have a significant influence on pasta properties [19].

The incorporation of different raw materials into wheat pasta has changed its cooking quality, nutritional value, and sensory attributes [1]. The present review summarises current research on common wheat pasta and durum wheat pasta enriched with different plant and animal raw materials and the effect of this enrichment on the quality, nutritional changes, and antioxidant activity of the final products.

\section{Enrichment of Pasta with Fruits and Vegetables}

Fruits and vegetables are a valuable source of many pro-health compounds, such as vitamins, fibre, minerals, carotenoids, glucosinolates, and polyphenols in particular, with strong antioxidant and anti-inflammatory properties [20]. Their strong antioxidant properties protect the human body from many diseases [9]. In recent years, many studies have been conducted on the enrichment of pasta by adding dried and powdered or pureed fruits, vegetables, or compounds extracted from these raw materials. Bustos et al. [21] studied the antioxidant, sensorial, and cooking quality of berry-enriched pasta. They partially replaced common wheat flour with freeze-dried and air-dried blackberry, raspberry, and black and red currant powder. Because of this enrichment, the content of polyphenol and anthocyanin content increased in pasta. Consequently, the enriched product showed increased antioxidant activity (ABTS (2,2'-azino-bis (3-ethylbenzothiazoline-6-sulfonic acid)) assay). The incorporation of berry, however, caused high swelling of pasta, which negatively influenced its cooking properties. Despite this drawback, enriched pasta samples were highly accepted by consumers. Berry-enriched pasta was perceived as fruity and tasty, with good firmness. Biernacka et al. [22] partially replaced wheat flour with banana powder and produced common wheat pasta. The enriched product had a higher level of total phenolics and enhanced antioxidant properties (ABTS assay and DPPH 
(2,2-diphenyl-1-picrylhydrazyl) assay) than the control product. The colour and cooking properties of the pasta also changed due to banana powder addition. Raw banana pasta was brighter in colour than the control product, whereas the opposite was true in the cooked pasta. Moreover, the optimal cooking time decreased and cooking losses increased with the increase in the percentage of banana powder in the pasta recipe. The incorporation of banana powder at a concentration greater than 3\% decreased the firmness of pasta and negatively influenced its sensory attributes. Additionally, other authors [23] found that the incorporation of ripe banana flour into pasta increased its resistance to enzyme digestion as compared to the unfortified product. Lucas-González et al. [4] studied the bioaccessibility of polyphenols and starch digestion of durum wheat pasta enriched with persimmon flour obtained from Diospyros kaki fruit. This tropical fruit belongs to the Ebenaceae family and contains many phytochemicals such as proanthocyanidin, tannins, flavonoids, and catechin [24]. The incorporation of persimmon flour into pasta changed its polyphenolic profile, wherein gallic acid and $p$-coumaric-o-hexoside in particular were detected in the enriched pasta. However, the content of phenolic compounds in raw pasta did not change following the incorporation of persimmon flour. Additionally, the bioaccessibility of polyphenols in pasta was poor, and the incorporation of persimmon flour did not improve it. Moreover, the cooked pasta showed decreased content of free polyphenols and decreased antioxidant activity (ABTS assay) in terms of the fraction of free phenolics. Importantly, ABTS values increased after the digestion process of pasta proportionally to the concentration of persimmon flour. Interestingly, the incorporation of $3 \%$ persimmon flour decreased the kinetics of starch digestion, but this effect was not observed when $6 \%$ persimmon flour was added. Other authors [25] incorporated unripe and ripe gac fruit (Momordica cochinchinensis) powder into common wheat pasta. They found that ripe fruit powder-enriched pasta with carotenoids such as lutein, zeaxanthin, $\beta$-cryptoxanthin, $\alpha$-carotene, and $\beta$-carotene. Moreover, the enriched pasta showed approximately twofold higher content of total phenolics and fourfold higher antioxidant activity (FRAP (ferric reducing antioxidant power) assay) than the control product. Interestingly, cooking did not significantly change the content of total phenolics and antioxidant activity but decreased the content of carotenoids. Additionally, the replacement of wheat flour with both unripe and ripe gac flour increased the total DF content by approximately twofold and decreased the carbohydrate content. Tolve et al. [26] used powdered and dried grape pomace for durum wheat pasta fortification. This fortification increased the cooking loss and firmness of pasta, but drastically decreased its swelling index. Importantly, the total phenolic content and antioxidant activity of raw and cooked pasta increased significantly after the addition of grape pomace as compared to the control product. However, despite the loss in phenolics during cooking, the enriched pasta still showed good antioxidant activity (FRAP and ABTS assays) due to the retention of phenolic compounds in the pasta. Moreover, the results of the starch digestibility test showed that the content of rapidly digestible starch and resistant starch slightly but significantly decreased, whereas that of slowly digestible starch increased. Consequently, the glycaemic index of pasta decreased from 57.5 (control pasta) to 53.2 (addition of $15 \%$ grape pomace). Additionally, the enriched pasta showed good sensory acceptability. Minarovičová et al. [27] replaced common wheat flour with powder obtained from dried celery root and dried sugar beet pulp. The incorporation of these ingredients into semolina led to higher absorption of water by the pasta product, because of the increase in the content of fibre. Moreover, the cooking loss increased due to the dilution of the protein network by fibre. Cooking loss is a commonly used index of pasta cooking quality and should not exceed $8 \%$ for good-quality pasta [28]. When the incorporation of both celery root and sugar beet pulp into pasta was $20 \%$, the cooking loss exceeded this value. Furthermore, the enrichment of pasta with powder from celery root resulted in an acceptable brown colour and pleasant flavour of the product, whereas the incorporation of root sugar beet pulp negatively affected these attributes. Additionally, both enriched pastas were softer and had a more granular structure than the control sample [27]. Other authors [29] used extracts prepared from artichoke canning by-products 
for wheat pasta fortification. According to their results, the enriched pasta showed $70 \%$ increased content of total phenolics (with a prevalence of luteolin-7-O-rutinoside) and approximately $50 \%$ higher antioxidant activity (ABTS assay) than the control product. Importantly, the added extract did not have a negative effect on the cooking quality and texture of pasta but decreased its lightness and yellowness. Djeukeu et al. [30] partially replaced semolina with yam flour (Dioscorea schimperiana). The enriched pasta showed a higher level of total phenolic content and enhanced antioxidant activity (DPPH, ABTS, and FRAP assays) but higher cooking loss and decreased firmness. Moreover, in vitro starch digestibility decreased with the increase in the percentage of yam flour, from $62 \%$ for control pasta to $50 \%$ for pasta with $60 \%$ yam flour. Additionally, yam flour decreased the lightness and yellowness of pasta. Other authors [31] incorporated sweet potato starch into wheat pasta. They found that this additive increased the content of resistant starch in the fortified product. However, the incorporation of this additive decreased the firmness and increased the stickiness of pasta. Consequently, the enriched pasta received lower scores for sensory evaluation. Vital et al. [32] used asparagus flour for functional pasta production. The content of total phenolics and flavonoids and the antioxidant activity (FRAP, DPPH, and ABTS assays) of the enriched pasta increased with the proportion of asparagus powder in the pasta recipe. Additionally, the proposed additive modified the chemical composition of the product; in particular, it increased the fibre content and protein content. The incorporation of asparagus flour into semolina also significantly influenced the pasta cooking properties, with a reduction in cooking time but with higher cooking loss and decreased water absorption of the product. Interestingly, the firmness and hardness of pasta increased with a higher concentration of this additive. The addition of this component also decreased the lightness and imparted yellow-green colouration to the product.

An interesting method of pasta fortification is the incorporation of puree from fruits and vegetables into wheat flour or semolina. This method of pasta enrichment is economically justified because the pureed material is added directly (without drying). Ponghal et al. [6] added blanched and pulped Syzygium cumini fruit directly into semolina during pasta production. This fruit is rich in many nutrients, exhibits strong antioxidant activity, and thus possesses several pharmacological characteristics [33]. They observed that the enriched pasta had increased total phenolic content and antioxidant activity (DPPH radical scavenging activity). The phenolic content increased from $111.2 \mathrm{mg}$ GAE (gallic acid equivalent)/g dry matter (d.m.) for control pasta (without enrichment) to $176.3 \mathrm{mg}$ GAE/g d.m. for pasta with $40 \%$ fruit pulp. Moreover, the fibre content in the pasta increased approximately twofold, and both the water absorption index and water solubility index also increased (from 1.65 to 2.38 and from $7.0 \%$ to $9.33 \%$, respectively). Additionally, the incorporation of fruit pulp into semolina resulted in lower lightness and yellowness of the product, but increased redness [6]. Rekha et al. [34] added puree from different vegetables (carrot, spinach, beetroot, and canned tomato puree) into wheat pasta. They found that the addition of vegetable purees led to an interaction between starch granules and the protein matrix, because of which the structure of dough from common wheat flour was enhanced. Consequently, the cooking loss and the swelling index of pasta decreased. However, the incorporation of vegetable puree decreased pasta firmness but increased the content of fibre and nutritional pigments such as carotene, chlorophyll, lycopene, and betalains. Moreover, the colour of the enriched pasta was more attractive, although the overall quality was slightly decreased. Only for pasta containing carrot puree, the overall quality of pasta was not significantly different from that of the control product.

To summarise, the enrichment of wheat pasta with fruits and vegetables is a very interesting future trend that enables more attractive pasta products to be obtained for consumers, in terms of not only enhanced sensory attributes but also increased nutritional and pro-health value (Table 1). It also frequently leads to an increase in starch bioavailability and consequently increases the glycaemic index of pasta [20]. On the other hand, such pasta enrichment results in the modification of the gluten network and causes higher water absorption of starch granules. These changes often have negative effects on the cooking 
quality and sensory attributes of pasta. Thus, the level of the individual ingredients has to be precisely estimated before their addition into pasta.

Table 1. Effect of wheat pasta fortification with fruits and vegetables.

Main Raw Materials and
Replacement Level

Semolina and pulp of

Syzygium cumini fruit $(10,20$,

30 , and $40 \%$ )

Common wheat flour and powder from unripe and ripe pulp of gac fruits

$(5,10$, and $15 \%)$

Common wheat flour and berry powder (blackberry, raspberry, black and red currant $(2.5 \%$ and $7.5 \%))$

Method of Pasta Production
and Drying Conditions

Main Effect and Recommended Level of

The dough was extruded through die into spiral shape and cut to $5 \mathrm{~cm}$, drying at $70{ }^{\circ} \mathrm{C}$ for $60 \mathrm{~min}$

The dough was laminated and cut into fettuccini form and dried at $60{ }^{\circ} \mathrm{C}$ for $18 \mathrm{~h}$

The dough was laminated and cut into strips of around $5 \mathrm{~mm}$ wide and $15 \mathrm{~cm}$ long. Pasta was then dried at $30^{\circ} \mathrm{C}$ for $30 \mathrm{~min}$ and at $45{ }^{\circ} \mathrm{C}$ at $75 \% \mathrm{RH}$ for $17.5 \mathrm{~h}$

Durum wheat semolina and grape pomace powder (5 and 10\%)

The dough was extruded (spaghetti die $1.75 \mathrm{~mm}$ ) and cut to $250 \mathrm{~mm}$ length. The pasta was air-dried at $50{ }^{\circ} \mathrm{C}$

The dough was extruded and vermicelli ( $3 \mathrm{~mm}$ diameter) was produced, pasta was dried at $25^{\circ} \mathrm{C}$ for $24 \mathrm{~h}$

Common wheat pasta and banana powder

$(1,2,3,4$, and $5 \%)$

Common wheat flour and asparagus flour $(5,10,15,20$, and $25 \%$ )

The dough was laminated and cut into strips. Pasta was then dried for $12 \mathrm{~min}$ at $30^{\circ} \mathrm{C}$ and for $3 \mathrm{~h}$ at $60^{\circ} \mathrm{C}$

Semolina and puree from different vegetables: carrot $(420 \mathrm{~g} / \mathrm{kg}$ flour wet basis $(f w b))$, spinach $\left(200 \mathrm{~g} / \mathrm{kg}_{\mathrm{fwb}}\right)$, beetroot $\left(150 \mathrm{~g} / \mathrm{kg}_{\mathrm{fwb}}\right)$, and canned tomato $\left(400 \mathrm{~g} / \mathrm{kg}_{\mathrm{fwb}}\right)$

Semolina and puree from different vegetables: carrot $(420 \mathrm{~g} / \mathrm{kg}$ flour wet basis $(f w b))$, spinach $\left(200 \mathrm{~g} / \mathrm{kg}_{\mathrm{fwb}}\right)$, beetroot $\left(150 \mathrm{~g} / \mathrm{kg}_{\mathrm{fwb}}\right)$, and canned tomato $\left(400 \mathrm{~g} / \mathrm{kg}_{\mathrm{fwb}}\right)$

Semi-coarse common wheat flour and powder from celery root and sugar beet pulp $(5,7.5,10$, and $20 \%)$

The dough was extruded using a single screw extruder die for spiral shaped pasta and cut to a length of $2.5 \mathrm{~cm}$; drying at $60{ }^{\circ} \mathrm{C}$ for $3 \mathrm{~h}$

The dough was extruded using a single screw extruder die for spiral shaped pasta and cut to a length of $2.5 \mathrm{~cm}$; drying at $60{ }^{\circ} \mathrm{C}$ for $3 \mathrm{~h}$

The dough was extruded and dried at temperature $25^{\circ} \mathrm{C}$ for three days

The dough was laminated $(0,9 \mathrm{~mm}$ sheet thick) and cut into strips ( $2 \mathrm{~mm}$ ) and $15 \mathrm{~cm}$ long.

Common wheat flour, water, and kañawa flour

$(10,20$, and $30 \%)$
Two steps drying: I-30 min at $30{ }^{\circ} \mathrm{C}$ without controlling humidity in an air convection drier; II-at $45^{\circ} \mathrm{C}$ in an air humidity $75 \%$ drier for $17.5 \mathrm{~h}$ Additive

Additive References

Enhanced antioxidant activity (AA) and

nutritional value of pasta, moderate effect on

the quality attributes. The recommended level

of fruit is $20 \%$ and $30 \%$

Decreased starch digestibility. Increased

content of dietary fibre and AA. The

recommended level of powder is $5 \%$ for unripe

gac fruit and from 5 to $15 \%$ for ripe gac fruit

Increased level of bioactive compounds in enriched pasta, increased TPC and AA, and improved sensory acceptance. The recommended level of berries in the pasta recipe is $2.5 \%$

Reduced glycaemic index and enhanced AA of pasta. The recommended level of proposed additives was not determined

Enhanced AA and increased TPC, reduced cooking time. The recommended level of banana powder is up to $3 \%$

Increased content of protein, TPC, TFC, and enhanced AA. The recommended level of proposed additives was not determined

More attractive colour of pasta with improved cooking quality, especially less cooking loss. Increased level of nutritional pigments but decreased firmness of pasta. The recommended level of proposed additives was not determined

More attractive colour of pasta with improved cooking quality, especially less cooking loss. Increased level of nutritional pigments but decreased firmness of pasta. The recommended level of proposed additives was not determined

Increased level of dietary fibre in pasta.

Negative influence on pasta cooking properties.

Good-quality pasta with celery roots up to $10 \%$

Increased level of dietary fibre in pasta.

Increased cooking loss, swelling index, and water absorption, decreased firmness. The recommended level of kañawa flour is up to $20 \%$ 
Table 1. Cont.

\begin{tabular}{lll}
\hline $\begin{array}{c}\text { Main Raw Materials and } \\
\text { Replacement Level }\end{array}$ & $\begin{array}{c}\text { Method of Pasta Production } \\
\text { and Drying Conditions }\end{array}$ & \multicolumn{1}{c}{$\begin{array}{c}\text { Main Effect and Recommended Level of } \\
\text { Additive }\end{array}$} \\
\hline $\begin{array}{l}\text { Semolina and yam flour } \\
(10,20,30, \text { and } 60 \%)\end{array}$ & $\begin{array}{l}\text { The dough was extruded at } \\
55{ }^{\circ} \mathrm{C} \text { for } 3 \mathrm{~h}\end{array}$ & $\begin{array}{l}\text { Enriched pasta was characterised by higher } \\
\text { level of total phenolics content and enhanced } \\
\text { antioxidant activity. In vitro starch digestibility } \\
\text { decreased with the percentage of yam flour }\end{array}$ \\
\hline $\begin{array}{l}\text { Semolina and persimmon } \\
(\text { Dyospyros kaki) flour } \\
(3 \text { and } 6 \%)\end{array}$ & $\begin{array}{l}\text { The dough was extruded } \\
\text { (spaghetti) and dried at } 50{ }^{\circ} \mathrm{C}\end{array}$ & $\begin{array}{l}\text { Increased gallic acid p-coumaric-o-hexoside in } \\
\text { enriched pasta, enhanced AA, decreased } \\
\text { kinetics of starch digestion. The recommended } \\
\text { for } 24 \mathrm{~h}\end{array}$ \\
\hline $\begin{array}{l}\text { Semol of persimmon flour is 3\% } \\
\text { cardoon roots and chicory } \\
(4 \%)\end{array}$ & $\begin{array}{l}\text { The dough was extruded } \\
\text { (spaghetti shape } 30 \mathrm{~cm} \text { in length } \\
\text { and } 1.7 \text { mm diameter). Drying } \\
\text { conditions were not included }\end{array}$ & $\begin{array}{l}\text { The inulin from cardamom was released to } \\
\text { higher extent in the digestive tract than inulin } \\
\text { from chicory. The recommended level of } \\
\text { additives was not determined }\end{array}$ \\
\hline
\end{tabular}

AA—antioxidant activity, TPC—-total phenolic content.

\section{Enrichment of Wheat Pasta with Grains and Seeds}

Seeds and grains, and their parts, by-products, or isolates, can be a valuable additive in the development of new pasta products. In recent years, numerous studies have discussed this issue. Littardi et al. [36] partially replaced wheat flour with chestnut flour in pasta production. They found that chestnut flour significantly increased the antioxidant activity (DPPH assay) in both raw and cooked pasta. Both chestnut flour and the cooking process increased the antioxidant activity of pasta. Moreover, the hardness of the product significantly decreased with the addition of chestnut flour because of the weak pasta structure. Gupta et al. [37] added quinoa protein isolate to semolina. Cooking loss and volume expansion of pasta increased following the incorporation of this additive into semolina. They attributed this phenomenon to the higher hydration capacity and fine particles of isolates. Importantly, the protein content of pasta increased from $11.73 \%$ for the control sample to $21.52 \%$ for pasta supplemented with $12.0 \%$ of protein isolates, whereas crude fat and carbohydrate content significantly decreased. Sensory evaluation showed that the incorporation of this additive decreased the overall acceptability of the product, especially when the proportion of protein isolates exceeded $8 \%$. Interestingly, the structural morphology analysis of pasta revealed that the control product had a smooth surface, while the supplemented pasta product had a rough surface with an irregular gluten network. Interestingly, the enriched pasta showed stronger firmness than the control sample. In another study [28], ground seed of kañawa (Chenopodium pallidicaule Aellen) was incorporated into common wheat pasta. Kañawa is an annual pseudocereal cultivated in Bolivia, Ecuador, and Peru. Seeds of this plant have a similar nutritive value as those of quinoa. Furthermore, they do not contain saponins as quinoa does and thus can be used directly as food [38]. The addition of kañawa into wheat flour resulted in higher water absorption and a higher swelling index of the pasta. Consequently, the enriched pasta showed decreased firmness and springiness and had a higher fibre content. Importantly, both fibre and protein content significantly increased after the cooking process as the percentage of kañawa in the pasta recipe increased. Microscopic pictures of kañawa-enriched pasta showed some holes and a disrupted protein matrix, with less ungelatinised starch granules [28]. Another study [39] analysed the effects of oat bran and whole barley flour addition on the physical and cooking quality of semolina pasta. The incorporation of fibre-rich components led to a shorter cooking time and darker pasta. A lower cooking loss was obtained when the addition of barley flour did not exceed $10 \%$. Cankurtaran and Bilgiçli [40] incorporated wheat bran and wheat germ into common wheat fresh pasta. The nutritive value of the enriched pasta significantly changed. The proposed additives increased the protein content and micronutrients in pasta. In particular, pasta enriched with wheat bran showed higher content of calcium, iron, and potassium, whereas pasta enriched with wheat germ showed 
higher content of magnesium, phosphorus, and zinc as compared to the control sample. Importantly, the incorporation of wheat germ and wheat bran increased the content of total phenolics and the antioxidant activity (DPPH assay) of pasta. However, high ratios (15-20\%) of these ingredients had a negative effect on the sensory and cooking quality of pasta. In another study [41], the authors added a debranning bran fraction from purple wheat into semolina. They observed that the level of anthocyanins and phenolics significantly increased following pasta enrichment. Similarly, Sethi et al. [42] incorporated black rice bran into wheat pasta. The content of protein, fat, crude fibre, minerals, and free fatty acids significantly increased as the percentage of rice bran in pasta increased. Most importantly, rice-bran-enriched pasta with anthocyanins showed increased antioxidant activity (DPPH and FRAP assays). The addition of bran, however, decreased the pasta firmness and brightness and increased the cooking loss. However, these changes had little influence on the sensory evaluation of pasta, and, in general, the enriched pasta received higher or slightly lower scores than the control product. An interesting study was recently reported by Alzuwaid et al. [43]. They incorporated into durum wheat pasta wheat bran protein concentrate. Consequently, the enriched pasta showed increased content of phytosterols, phenolic acids, and protein. Importantly, enrichment of pasta with protein concentrate did not have a negative influence on pasta in vitro starch digestion. In another study, Teterycz et al. [18] used flour of legume seeds (green pea, red lentil, and grass pea) for the partial replacement of durum wheat semolina in pasta production. The enriched pasta showed significantly increased fibre and protein content. Moreover, the enriched pasta was more yellow and darker, with increased firmness compared to the control sample. The incorporation of legume flour, however, had a negative influence on the cooking properties of pasta. The cooking loss of the enriched pasta increased and the weight increase index decreased as compared to the control product. An interesting study was conducted by Biernacka et al. [16]. They enhanced the nutritional and antioxidant properties of pasta by adding cereal coffee into common wheat flour. Cereal coffee is prepared mainly from the roasted grains of barley and rye. It is rich in fibre and bioactive compounds [44]. Enrichment of pasta with cereal coffee increased the total phenolic content by approximately twofold when wheat flour was replaced with $5 \%$ cereal coffee. Moreover, both the raw and cooked products showed increased antioxidant activity (ABTS and CHEL (chelating antioxidant power) assays). Additionally, pasta with cereal coffee had a shorter cooking time and higher cooking loss than the control sample. Importantly, the addition of cereal coffee into common wheat flour at up to $4 \%$ improved the sensory quality of pasta. In one study, the authors partially replaced semolina with flaxseed flour and flaxseed cake [45]. Both these additives decreased the cooking loss of pasta and increased the weight of pasta after cooking. The whiteness index and firmness of pasta also decreased. Importantly, the enriched pasta showed higher content of protein, fat, and fibre than the control sample. However, the energetic value of enriched pasta did not change significantly. Interesting results were reported by Arnibar et al. [46] and Pigni et al. [47]. They added partially deoiled chia flour into common wheat pasta. Consequently, the fortified pasta showed increased content of protein, fibre, and omega- 3 fatty acids. Additionally, the total phenolic content and the antioxidant activity (FRAP assay) of the enriched pasta were increased with the increase in the concentration of chia flour. This tendency was observed for both raw and cooked pasta. Cooking generally had little influence on the total phenolic content and the antioxidant activity of the fortified product, but it increased the phenolic content and FRAP in the control pasta. Consequently, the enriched pasta (containing up to $5 \%$ of partially deoiled chia flour) received similar scores for taste, smell, and firmness to the control product. Ten months of storage of pasta resulted in similar sensory scores for the control and enriched pasta products. Importantly, the incorporation of chia flour had a positive effect on pasta cooking properties (shorter cooking time and lower cooking loss) and did not have a negative effect on pasta firmness and adhesiveness [46]. The HPLCMS analysis of partially deoiled chia-enriched pasta showed the presence of 14 phenolic compounds, and most of these compounds were hydroxycinnamic acids, with prominent 
abundance (tenfold as compared to the remaining detected compounds) of rosmarinic acid and its glycosylated derivative [47]. These compounds show many remarkable biological effects on human health, with anti-inflammatory, antibacterial, anticancer, and antiallergic properties [48]. The simulated gastrointestinal digestion of pasta also showed that only a small amount of polyphenols is absorbed in the small intestine, while the majority of these compounds enter the colon. Importantly, rosmarinic acid and its glycoside were detected in the intestine [47], allowing others to replicate and build on the published results. Other authors [49] incorporated defatted hemp flour (Cannabis sativa L.) into durum wheat pasta. This additive enhanced the pasta's protein, dietary fibre and mineral content but had a negative effect on the taste and smell. Pasta with $30 \%$ of hemp flour was characterised by satisfactory sensory properties and good cooking quality.

In recent years, einkorn wheat (Triticum monococcum L. subsp. monococcum) has been used as a pasta ingredient. This diploid wheat is a promising candidate for the production of cereal products because of its positive nutritional features. Einkorn grain is characterised by a higher content of protein, tocols, carotenoids, conjugated polyphenols, microelements, and phytosterol compared to the grain of polyploid wheat [50]. In addition, low $\beta$-amylase and lipoxygenase activities decrease antioxidant degradation during einkorn grain and flour processing [51,52]. Brandolini et al. [53] compared the quality of pasta prepared from einkorn, durum, and bread wheat. They found that einkorn pasta was less firm but had lower cooking losses and better nutritional value than durum wheat and bread wheat pasta. Hidalgo et al. [50] produced wheat pasta from einkorn flour (five types of einkorn wheat pasta were prepared: einkorn, pregerminated einkorn, decorticated einkorn, einkorn-egg albumen, and einkorn-whole egg pasta). All the einkorn pasta products showed lower heat damage and higher protein and carotenoid content than the control durum wheat product. Additionally, cooked einkorn pasta samples were more yellow and cooking loss was always lower in the einkorn products than in the durum wheat pasta. Other authors [54] showed significant differences in structure and starch digestion of pasta made with einkorn and durum wheat. Pasta produced from einkorn flour showed a less compact structure and a lower rate of starch hydrolysis compared to the durum product. This can be explained by the differences in the gluten properties of durum and einkorn pasta and the higher ability of durum pasta in binding water [54]. Recently, Nocente et al. [55] incorporated brewers' spent grain from einkorn wheat into durum wheat pasta. The enriched pasta showed higher protein content, dietary fibre, and antioxidant activity (trolox equivalent) than the control durum wheat product. Importantly, enrichment of durum wheat pasta with brewers' spent grain did not negatively affect its sensory quality.

An interesting trend is the enrichment of cereal products with fermented seeds. Seed fermentation is recognised as an effective tool to improve the nutritional properties of different seeds and to reduce the content of antinutritional compounds [56]. Soluble fibres, total phenolic content, free amino acids, and protein digestibility significantly increased during seed fermentation [57]. In the study conducted by Rizzello et al. [58], wheat pasta was fortified with fermented faba bean flour. A $50 \%$ replacement of semolina with fermented faba bean flour resulted in twofold higher content of protein, fat, ash, and total DF than that in the control sample. Importantly, the content of essential amino acids such as lysine, methionine, and threonine increased significantly (from $44.5 \%$ to $70.2 \%$ ). The enriched samples also showed a lower glycaemic index and a higher level of resistant starch. A 30\% replacement of semolina with bean flour increased pasta firmness without negatively affecting its sensory quality. Lorusso et al. [59] incorporated fermented quinoa flour into pasta. Pasta enriched with this additive ( $20 \%$ of semolina replacement) exhibited improved nutritional value (higher fibre, protein, and free amino acid content), low glycaemic index, improved protein digestibility, and higher antioxidant activity than the control sample. The tenacity and elasticity of the enriched pasta also increased following the addition of fermented quinoa flour. Importantly, the enriched pasta showed improved flavour and taste attributes as compared to the control sample. Quinoa addition decreased the optimum cooking time and water absorption, but increased the cooking loss. 
Considering the above findings, it could be concluded that various seeds and byproducts of their processing as well as fermented grain or flour can be a valuable additive for increasing the nutritional value of pasta (Table 2). On the other hand, such additives have often negative effects on the cooking quality of pasta.

Table 2. Effect of cereal grain and seed addition on nutritional value of wheat pasta.

\begin{tabular}{|c|c|c|c|}
\hline $\begin{array}{l}\text { Main Raw Materials and } \\
\text { Replacement Level }\end{array}$ & $\begin{array}{l}\text { Method of Pasta Production } \\
\text { and Drying Conditions }\end{array}$ & $\begin{array}{c}\text { Main Effect and Recommended Level of } \\
\text { Additive }\end{array}$ & References \\
\hline $\begin{array}{l}\text { Semolina and quinoa protein } \\
\text { isolates }(4,8 \text {, and } 12.0 \%)\end{array}$ & $\begin{array}{l}\text { The dough was extruded at a } \\
\text { temperature of } 37-40{ }^{\circ} \mathrm{C} \text {, using } \\
\text { shell-shaped die. Pasta was cut } \\
\text { to length of } 2.5 \mathrm{~cm} \text { and dried at } \\
45-50{ }^{\circ} \mathrm{C} \text { for } 4-5\end{array}$ & $\begin{array}{l}\text { Enrichment of pasta in protein (especially in } \\
\text { methionine and lysine), higher firmness, but } \\
\text { increased cooking loss. Recommended level of } \\
\text { inclusion of quinoa protein isolates is up to } \\
8.0 \%\end{array}$ & [37] \\
\hline $\begin{array}{l}\text { Common wheat flour and } \\
\text { partially deoiled chia flour } \\
(2.5,5 \text {, and } 10 \%)\end{array}$ & $\begin{array}{l}\text { The dough was laminated and } \\
\text { cut into strings } \\
(2 \times 2 \times 200 \mathrm{~mm})\end{array}$ & $\begin{array}{l}\text { Enhanced nutritional value of pasta. Increased } \\
\text { TPC and AA. Enrichment of wheat pasta with } \\
\text { rosmarinic acid and its glycosylated form. The } \\
\text { recommended level of proposed additive was } \\
\text { not determined }\end{array}$ & {$[45,46]$.} \\
\hline $\begin{array}{l}\text { Semolina and chemp flour ( } 5 \text {, } \\
10,15,20,25,30,35 \text {, and } 40 \%)\end{array}$ & $\begin{array}{l}\text { The dough was extruded and } \\
\text { pasta (Fusilli) was dried } \\
\left(35-55^{\circ} \mathrm{C}\right) \text { at } 85-55 \% \mathrm{RH}\end{array}$ & $\begin{array}{l}\text { Enrichment of pasta in protein, fibre, ash, and } \\
\text { fat content. Recommended level of chemp } \\
\text { flour: } 30 \%\end{array}$ & [49] \\
\hline $\begin{array}{l}\text { Semolina and einkorn } \\
\text { brewers' spent grain } \\
(5 \text { and } 10 \%)\end{array}$ & $\begin{array}{l}\text { The dough was extruded and } \\
\text { pasta (macaroni shape) was } \\
\text { dried for } 18 \mathrm{~h} \text { at } 58^{\circ} \mathrm{C}(\max ) \\
\text { and } 70-85 \mathrm{RH}\end{array}$ & $\begin{array}{l}\text { Enrichment of pasta in } \beta \text {-glucan content and } \\
\text { increased AA. Recommended level of einkorn } \\
\text { brewers' spent grain is up to } 10.0 \%\end{array}$ & [55] \\
\hline
\end{tabular}

Semolina, oat bran, wholemeal barley flour, resistant starch (each additive at 5,10 , and $15 \%$ )

Semolina and black rice bran $(5,10,15,20$, and $25 \%)$.

Semolina and wheat bran protein concentrate $(1,5,10$, and $20 \%$ )

Common wheat flour, egg, wheat bran and germ both at $5,10,15$, and $20 \%$ in relation to wheat flour

Semolina and legume flours: green pea, lentil flour, and grass pea flour $(5,10,15$, and $20 \%)$

Semolina and fermented faba bean flour $(10,30$, and 50\%)
The dough was extruded into spiral-shaped pasta and pasta was dried at $71^{\circ} \mathrm{C}$ for $6 \mathrm{~h}$

The dough was extruded (spiral shape) and dried at $50{ }^{\circ} \mathrm{C}$ for 3-4h

The dough was extruded (spaghetti) and dried at $65{ }^{\circ} \mathrm{C}$ at $70 \% \mathrm{RH}$ for $45 \mathrm{~min}$ then at $50{ }^{\circ} \mathrm{C}, \mathrm{RH} 70-80 \%$ for $13 \mathrm{~h}$

The dough was laminated and then put into ravioli mold. Steam $\left(91^{\circ} \mathrm{C}\right.$ for $9 \mathrm{~min}$ ) was applied to all products. Immediately after steaming, the pasta was cooled to room temperature

The dough was laminated. The dough sheets were cut (strands of $7 \mathrm{~mm}$ wide and $500 \mathrm{~mm}$ long). Pasta was dried at $35-55{ }^{\circ} \mathrm{C}$ for $7 \mathrm{~h}$, humidity was changed from $75 \%$ to $55 \%$

The dough was extruded and cut into short forms (grooved "macaroni"). Pasta was dried at $55^{\circ} \mathrm{C}$
Enrichment of pasta in fibre and decreased cooking loss. The recommended level of both proposed additives is up to $5 \%$

Improved nutritional value of pasta, enrichment pasta in anthocyanins, and enhanced AA of pasta. The recommended level of proposed additive was not determined

Increased content of protein, phytosterols, and phenolics in fortified pasta. The recommended level of bran protein concentrate is 10 and $20 \%$

Enhanced nutritional profile and AA of pasta. The recommended level of bran and germ is up to $10 \%$ and $15 \%$, respectively

The content of lysine in fortified pasta was increased by $60-88 \%$. Increased yellowness and firmness of pasta. The recommended level of proposed additive was not determined

Increased content of amino acids (lysine, methionine, and threonine). Decreased glycaemic index. The recommended level of replacement of semolina with fermented faba 
Table 2. Cont.

\begin{tabular}{|c|c|c|c|}
\hline $\begin{array}{l}\text { Main Raw Materials and } \\
\text { Replacement Level }\end{array}$ & $\begin{array}{l}\text { Method of Pasta Production } \\
\text { and Drying Conditions }\end{array}$ & $\begin{array}{c}\text { Main Effect and Recommended Level of } \\
\text { Additive }\end{array}$ & References \\
\hline $\begin{array}{l}\text { Semolina and fermented } \\
\text { quinoa flour }(20 \%)\end{array}$ & $\begin{array}{l}\text { The dough was extruded and } \\
\text { cut into short forms (grooved } \\
\text { "macaroni"). Pasta was dried at } \\
55^{\circ} \mathrm{C}\end{array}$ & $\begin{array}{l}\text { Increased nutritional value of pasta (dietary } \\
\text { fibre, protein, and free amino acids content), } \\
\text { improved protein digestibility, and enhanced } \\
\text { antioxidant activity. The recommended level of } \\
\text { proposed additives was not determined }\end{array}$ & [59] \\
\hline $\begin{array}{l}\text { Common wheat flour and } \\
\text { cereal coffee }(1,2,3,4 \text {, and } 5 \%)\end{array}$ & $\begin{array}{l}\text { The dough was laminated. The } \\
\text { dough sheets were cut (strands } \\
\text { of } 7 \mathrm{~mm} \text { wide and } 500 \mathrm{~mm} \text { long). } \\
\text { Pasta was dried at } 24^{\circ} \mathrm{C} \text { for } 25 \mathrm{~h}\end{array}$ & $\begin{array}{l}\text { Enhanced TPC and AA. Positive influence of } \\
\text { taste, smell, and colour of pasta. The } \\
\text { recommended level of cereal coffee up to } 4 \%\end{array}$ & [16] \\
\hline $\begin{array}{l}\text { Semolina and flaxseed flour, } \\
\text { and flaxseed cake }(5,9,13,17 \text {, } \\
20,23 \%)\end{array}$ & $\begin{array}{l}\text { The dough was extruded. Pasta } \\
\text { was dried at temperature from } \\
35 \text { to } 55^{\circ} \mathrm{C} \text { in a } 7 \mathrm{~h} \text { drying cycle }\end{array}$ & $\begin{array}{l}\text { Enriched pasta in fibre, fat, and protein. The } \\
\text { enrichment of pasta with } 23 \% \text { flaxseed flour } \\
\text { and } 17 \% \text { flaxseed cake is recommended }\end{array}$ & [45] \\
\hline $\begin{array}{l}\text { Common wheat flour and } \\
\text { chestnut flour }(20,30 \text {, and } \\
40 \%)\end{array}$ & $\begin{array}{l}\text { Then, the dough was laminated } \\
\text { up to } 1 \mathrm{~mm} \text { thickness and sheets } \\
\text { were cut into "tagliatelle" shape }\end{array}$ & Enhanced AA and decreased hardness of pasta & {$[36]$} \\
\hline
\end{tabular}

AA—antioxidant activity, TPC—-total phenolic content.

\section{Enrichment of Pasta with Animal Raw Materials}

An interesting trend in recent years has been the addition of animal raw materials such fish, insects, or meat by-products into pasta (Table 3). These types of materials are considered to be healthy and nutritious as they have a rich content of protein, beneficial fat, fibre, vitamins, and minerals [14,52,60]. Duda et al. [14] incorporated edible cricket in powder form into semolina pasta. Edible cricket powder is a valuable source of protein, unsaturated fatty acids, fibre, and minerals, especially zinc, calcium, and iron [61]. The substitution of semolina with cricket powder significantly enhanced the nutritional value of pasta. The content of protein, fat, and ash increased in pasta, whereas carbohydrate content decreased after adding cricket powder. The highest changes were noted in fat content (increase from $1.31 \%$ for control pasta to $4.73 \%$ for pasta enriched with $15 \%$ of cricket powder). Moreover, the energetic value of pasta significantly increased with the addition of cricket powder. This additive also increased the optimum cooking time and firmness of pasta, while decreasing cooking loss and lightness. Importantly, more than 5\% addition of cricket powder negatively affected pasta sensory attributes. Other authors [62] found that cricket powder significantly increased the total phenolic content and the antioxidant activity (FRAP assay) of pasta. In another study, Çabuk and Yilmaz [63] investigated the influence of grasshopper flour and mealworm flour addition on the properties of wheat pasta. Similar to the study of Pauter et al. [61], the incorporation of edible insects into pasta increased the protein content and decreased the starch content in the final product. Moreover, the enriched pasta product (with 15\% insect powder) showed approximately twofold higher content of crude fibre than the control sample. The colour of pasta also significantly changed after the addition of powdered insects; in particular, the lightness and yellowness of pasta decreased. Additionally, the sensory evaluation showed that partial replacement of wheat flour with both kinds of insect powder decreased notes for pasta sensory attributes such as colour, odour, and smoothness. 
Table 3. Incorporation of powdered animal materials into pasta and its effect on pasta quality.

\begin{tabular}{|c|c|c|c|}
\hline $\begin{array}{l}\text { Main Raw Materials and } \\
\text { Replacement Level }\end{array}$ & $\begin{array}{l}\text { Method of Pasta Production } \\
\text { and Drying Conditions }\end{array}$ & $\begin{array}{c}\text { Main Effect and Recommended Level of } \\
\text { Additive }\end{array}$ & References \\
\hline $\begin{array}{l}\text { Semolina and smoked trout } \\
\text { fillet powder }(5,10,15,20 \text {, } \\
\text { and } 25 \%)\end{array}$ & $\begin{array}{l}\text { The dough was extruded (die } \\
6 \mathrm{~mm} \text { wide, } 0.85 \mathrm{~mm} \text { thick) and } \\
\text { cut to } 10 \mathrm{~cm} \text {. Drying at room } \\
\text { temperature for around } 20 \mathrm{~h}\end{array}$ & $\begin{array}{l}\text { Enhanced nutritional value of pasta and } \\
\text { increased level of TPC and AA. Decreased } \\
\text { cooking quality and sensory attributes. The } \\
\text { recommended level of trout powder is up } \\
\text { to } 15 \%\end{array}$ & [15] \\
\hline $\begin{array}{l}\text { Semolina and red cod fish } \\
\text { powder }(5,10,15 \text {, and } 20 \%)\end{array}$ & $\begin{array}{l}\text { The dough was extruded } \\
(2.25 \mathrm{~mm} \text { diameter die) and } \\
\text { extruded fresh pasta was frozen } \\
\text { at }-18^{\circ} \mathrm{C}\end{array}$ & $\begin{array}{l}\text { Enhanced protein ash and fat level of enriched } \\
\text { pasta. Increased firmness but decreased } \\
\text { cooking quality and sensory attributes. The } \\
\text { recommended level of proposed additives was } \\
\text { not determined }\end{array}$ & [64] \\
\hline $\begin{array}{l}\text { Semolina and cricket powder } \\
(5,10 \text {, and } 15 \%)\end{array}$ & $\begin{array}{l}\text { The dough was extruded and } \\
\text { pasta was dried as follows: } \\
45^{\circ} \mathrm{C}, \mathrm{RH}=75 \% \text { for } 3 \mathrm{~h} ; 63^{\circ} \mathrm{C}, \\
\mathrm{RH}=85 \% \text { for } 12 \mathrm{~h} \text { and } 40^{\circ} \mathrm{C} \\
\mathrm{RH}=60 \% \text { for } 4 \mathrm{~h}\end{array}$ & $\begin{array}{l}\text { Enhanced nutritional value of pasta. Decreased } \\
\text { sensory attributes. Application of cricket } \\
\text { powder at the amount of } 5 \% \text { is recommended }\end{array}$ & [61] \\
\hline $\begin{array}{l}\text { Common wheat flour, eggs, } \\
\text { and edible insects (mealworm } \\
(15 \%) \text { and grasshopper } \\
\text { flour }(15 \%))\end{array}$ & $\begin{array}{l}\text { The dough was laminated and } \\
\text { cut into pieces with regular } \\
\text { thickness. Flattened pieces were } \\
\text { dried }\left(60^{\circ} \mathrm{C}, 10 \mathrm{~min}\right) \text { and cut } \\
\text { into } 3 \mathrm{~cm} \text { long stripes. The } \\
\text { second drying was performed } \\
\text { at } 60^{\circ} \mathrm{C} \text { for } 90 \mathrm{~min}\end{array}$ & $\begin{array}{l}\text { Improved nutritional value of pasta but } \\
\text { decreased cooking quality and sensory } \\
\text { attributes. The recommended level of } \\
\text { proposed additives was not determined }\end{array}$ & [63] \\
\hline $\begin{array}{l}\text { Common wheat flour and } \\
\text { tilapia waste flour }(10,20,30, \\
\text { and } 40 \% \text { of wheat flour })\end{array}$ & $\begin{array}{l}\text { Dough was laminated and cut } \\
\text { into pieces ( } 260 \mathrm{~mm} \text { length and } \\
5 \mathrm{~mm} \text { width). Pasta was dried } \\
\text { at } 45^{\circ} \mathrm{C} \text { for } 2 \mathrm{~h} \text {, with a drying } \\
\text { air velocity of } 1.5 \mathrm{~m} / \mathrm{s}\end{array}$ & $\begin{array}{l}\text { Enhanced nutritional value of pasta without } \\
\text { negative influence on pasta cooking quality } \\
\text { and sensory attributes when the level of tilapia } \\
\text { powder did not exceed } 10 \%\end{array}$ & [65] \\
\hline $\begin{array}{l}\text { Semolina and pangas protein } \\
\text { isolates }(2.5,5.0,7.5, \\
\text { and } 10.0 \%)\end{array}$ & $\begin{array}{l}\text { The dough was extruded at } \\
37-40{ }^{\circ} \mathrm{C} \text {. The pasta was dried } \\
\text { (Penne/tube-shaped) at } 50{ }^{\circ} \mathrm{C} \\
\text { with a relative humidity of } \\
60-70 \% \text { for } 4-5 \mathrm{~h}\end{array}$ & $\begin{array}{l}\text { Enhanced nutritional value of pasta. Improved } \\
\text { colour but increased optimum cooking time } \\
\text { and cooking loss. The recommended level of } \\
\text { pangas protein isolates is up to } 5 \%\end{array}$ & [66] \\
\hline $\begin{array}{l}\text { Semolina and pangas protein } \\
\text { isolates }(2.5,5.0,7.5 \text {, } \\
\text { and } 10.0 \%)\end{array}$ & $\begin{array}{l}\text { The dough was extruded (penne } \\
\text { form) and dried at } 50{ }^{\circ} \mathrm{C} \text { for } 5 \mathrm{~h}\end{array}$ & $\begin{array}{l}\text { Enrichment of pasta with essential amino acids. } \\
\text { Increased fish flavour of pasta. The } \\
\text { recommended level of pangas protein isolates } \\
\text { is up to } 5 \%\end{array}$ & [67] \\
\hline $\begin{array}{l}\text { Semolina and beef emulsion } \\
\text { (beef meat was mixed with } \\
\text { distilled water }(1: 1)) \text {. The level } \\
\text { of semolina replacement: } 15 \text {, } \\
30 \text {, and } 45 \%\end{array}$ & $\begin{array}{l}\text { The dough was extruded and } \\
\text { fresh pasta was used } \\
\text { for analysis }\end{array}$ & $\begin{array}{l}\text { Increased protein and fat content in fortified } \\
\text { pasta. Decreased glycaemic index and } \\
\text { enhanced tensile strength and elasticity of } \\
\text { pasta. The recommended level of beef } \\
\text { emulsion is up to } 45 \%\end{array}$ & [68] \\
\hline $\begin{array}{l}\text { Semolina and beef lung } \\
\text { powder }(10,15 \text {, and } 20 \%)\end{array}$ & $\begin{array}{l}\text { The dough was extruded } \\
\text { (spaghetti) and fresh pasta } \\
\text { was produced }\end{array}$ & $\begin{array}{l}\text { Improved nutritional quality (enriched pasta } \\
\text { in dietary fibre, calcium, and iron). The } \\
\text { recommended level of beef lung powder: } 10 \%\end{array}$ & [69] \\
\hline
\end{tabular}

$$
\text { AA—antioxidant activity, TPC—-total phenolic content. }
$$

In recent years, the enrichment of pasta with by-products of fish processing has also become popular. Fish powder is a cheap source of high-quality nutrients with a high level of essential amino acids, polyunsaturated fatty acids, vitamins, and minerals [64]. Ozgoren and Yapar [15] added smoked trout fillet powder (production waste material) to durum wheat pasta. Partial replacement of semolina with smoked trout significantly enhanced the nutritional value of pasta. Protein content and fat content in pasta increased from 13.87\% to $25.76 \%$ and from $1.70 \%$ to $7.88 \%$, respectively, with the addition of trout powder from 
$0 \%$ to $25 \%$. The enrichment also decreased the carbohydrate level from $73.66 \%$ to $53.63 \%$, and consequently, the energy value of pasta increased from 365.39 to $388.4 \mathrm{kcal} / 100 \mathrm{~g}$. Importantly, the replacement of semolina with smoked trout significantly increased the total phenolic content (from $35.93 \mathrm{mg}$ GAE/100 g for control to $42.21 \mathrm{mg}$ GAE)/100 g for pasta with $25 \%$ trout addition and increased the antioxidant activity (DPPH assay) by several times. The enriched pasta showed increased optimum cooking time and cooking loss, with decreased water absorption and swelling index. Moreover, the sensory analysis showed that the addition of trout powder negatively affected pasta odour, taste, and texture, and therefore, the percentage of the trout powder in the pasta recipe should not exceed $15 \%$. Monteiro et al. [65] studied the physicochemical and sensory characteristics of common wheat pasta enriched with tilapia waste flour. Similar to insect powder, tilapia powder improved the nutritional composition of pasta. The enriched pasta showed significantly increased protein content and ash content and decreased carbohydrate content. Control pasta had $9.1 \%$ protein content and $1.9 \%$ lipid content, whereas pasta enriched with $23 \%$ tilapia waste powder showed $18.4 \%$ and $4.9 \%$ content of these compounds, respectively. The cooking time, water absorption, and swelling index of pasta decreased, and cooking loss increased following the addition of tilapia powder. These changes resulted in the enriched pasta becoming harder and showing less springiness. Moreover, the lightness and yellowness of pasta decreased with the addition of tilapia powder, but redness increased. Importantly, the replacement of $10 \mathrm{~g} / 100 \mathrm{~g}$ of wheat flour with tilapia powder had no negative influence on the sensory quality of pasta. In some other studies, the authors incorporated protein isolates from pangas waste into semolina pasta [58,59]. They found that these isolates significantly increased the protein content of pasta and altered the cooking characteristics of the product. An increase in the content of protein isolates extended the optimum cooking time from 6.5 to $8.5 \mathrm{~min}$ and increased the water uptake ratio, volume expansion ratio, and cooking loss [66]. Moreover, Singh et al. [67] reported that protein isolates from pangas decreased the firmness and toughness of pasta when the concentration of this additive did not exceed $7.5 \%$. These indices of pasta texture are very important parameters for pasta quality assessment and are related to the strength of the protein network and swelling of starch granules [70]. Notably, protein isolates from pangas showed no significant influence on pasta appearance, colour, and palatability and had a less negative influence on pasta flavour. The incorporation of protein isolates led to a rougher surface of the pasta and a compact starch structure deeply embedded into the nongluten protein matrix, which resulted in a longer time for starch gelatinisation. In another study by Desai et al. [71], semolina was partially replaced with salmon (Oncorhynchus tschawytscha) powder, and fresh pasta was produced. Similar to the study conducted by other authors [66], protein, fat, and ash contents were found to be significantly increased following the addition of fish powder into pasta. However, the cooking properties of pasta decreased. The cooking loss increased by approximately twofold (above 8\%) as compared to that in the control sample when $20 \%$ wheat flour was replaced with salmon powder. Moreover, the firmness of cooked pasta was decreased after the incorporation of fish powder into semolina. These changes were mainly caused by the disruption of the starch-protein matrix by salmon flour. Desai et al. [64] also conducted a study on the effect of red cod fish (Pseudophycis bachus) powder addition on the nutritional profile and physical properties of durum wheat pasta. The fortification of pasta with $20 \%$ red cod fish powder increased the content of protein, fat, and ash in pasta by approximately twofold as compared to that in the control product. In contrast to the results obtained for salmon-enriched pasta [69], red cod-enriched pasta showed enhanced firmness and resistance to uniaxial extension as compared to the control product, which was probably due to decreased water absorption during cooking. Moreover, the cooking quality of the fortified product decreased. Red cod-enriched pasta exhibited higher cooking loss and lower water absorption during cooking. The sensory evaluation of red cod-enriched pasta was, however, not performed. 
Jayawardena et al. [69] incorporated beef lung powder into durum wheat pasta. Beef lungs are a rich source of protein and iron [72]. As compared to the control product, the enriched pasta exhibited a higher content of amino acids. The lysine content in particular increased by approximately twofold in the enriched pasta. Moreover, the firmness of pasta increased following lung powder addition. The cooking loss of the enriched pasta was, however, significantly higher than that of the control sample. Both cooked and uncooked pasta were darker and more red in colour with the addition of lung powder, whereas the yellowness of pasta decreased. Importantly, the addition of $10 \%$ lung powder into pasta increased the iron content by fivefold, increased the protein content by $60 \%$, and improved the score of essential amino acids (from 0.48 to 0.91) [69]. In another study, Lin et al. [68] investigated the nutritional value and structure of pasta enriched with beef emulsion. The glycaemic index of pasta significantly decreased with the increase in the percentage of this additive. Moreover, the fortified pasta showed higher protein, fat, and ash content than the control product. The study of pasta microstructure revealed that beef emulsion enhanced the protein matrix. Because of this enhancement, the tensile strength and elasticity of the enriched pasta increased, which was positively received by the consumers. Additionally, beef-enriched products were more preferred in terms of flavour than the control pasta. This phenomenon could be attributed to the presence of reducing sugars and amino acids in the enriched pasta because of the occurrence of the Maillard reaction during pasta cooking. This reaction generated heterocyclic compounds responsible for the meaty flavour of the enriched product. Boundalia et al. [73] obtained interesting results when sweet whey was used for pasta enrichment. The replacement of semolina with $20 \%$ powdered whey in pasta production significantly increased the protein content, but did not negatively affect the sensory attributes of pasta. Moreover, the cooking properties of the enriched pasta only slightly altered following whey addition.

To summarise, the enrichment of pasta with animal raw materials effectively enhances its nutritional value. In particular, the enriched pasta shows increased protein and fat content and decreased carbohydrate content. Such fortification, however, frequently has a negative effect on pasta quality in terms of higher cooking loss and decreased sensory acceptability (Table 3).

\section{Enrichment of Pasta with Herbs, Spices, and Different Parts of Plants}

In recent years, some researchers have been studying the possibility of enriching pasta with herbal raw materials (Table 1). Padalino et al. [74] enriched durum wheat fresh pasta with an extract from the Salicornia europaea plant. This is an annual herbal plant with enhanced anti-inflammatory and anticancer properties [75]. The addition of the $S$. europaea extract into durum wheat semolina showed little influence on the cooking quality and sensory attributes of pasta and increased the total phenolic content, total flavonoid content, and antioxidant activity (DPPH and ABTS assays) of the enriched product. Interestingly, the content of this compound significantly decreased after cooking; however, the antioxidant activity did not change significantly. Importantly, the results of pasta digestion confirmed that the S. europaea extract enriched durum wheat pasta, with high total phenolic content and enhanced antioxidant (FRAP assay) properties. Lisiecka et al. [76] added Cistus incanus L. leaves into common wheat pasta. C. incanus L. is a medicinal plant with anti-inflammatory, antiulcerogenic, and antimicrobial properties and is commonly used in herbal infusions [77]. Following the incorporation of the Cistus leaves into pasta, the total phenolic content and antioxidant properties of pasta (DPPH and ABTS assays) significantly increased. The replacement of wheat flour with 5\% Cistus leaves resulted in an approximately twofold increase in the total phenolic content as compared to that of control pasta and changed the colour of the enriched product. Both raw and cooked pasta showed an increase in redness and yellowness. However, the enrichment of pasta with this herb significantly increased the cooking loss and decreased the sensory attributes, particularly when the amount of addition exceeded 3\%. Among the wide variety of spices, saffron (dried and powdered Crocus sativus L. flowers) has received special attention in the 
food industry because of its pleasant aroma and pro-health and colouring properties [78]. Armellini et al. [79] incorporated saffron extract into durum wheat flour pasta and found that this additive decreased the starch digestibility and glycaemic index of the enriched pasta. Furthermore, the addition of saffron led to the release of crocin (a major component responsible for the colour of saffron) in the digestive fluids.

Leaves of different plants are a valuable source of many bioactive compounds with pro-health properties and can be used as functional additives in foods. Recently, Simonato et al. [80] incorporated Moringa oleifera L. leaf powder into wheat pasta. The leaves of this plant enriched pasta with phenolic compounds, DF, protein, and minerals. The total phenolic content and antioxidant activity (FRAP and ABTS assays) were also significantly increased in the fortified pasta. However, this effect was partially reduced after the cooking process. The cooked pasta showed a decrease in the total phenolic content, antioxidant activity, and micro- and macro-elements. Pasta enriched with Moringa leaves also showed lower firmness, darker colour, herbaceous aroma, and higher cooking loss. However, these changes had no significant influence on the overall acceptability of the enriched product. Other authors [81] added amaranth flour and dried and powdered leaves of amaranth to durum wheat pasta. The leaves of amaranth significantly increased the total phenolic content and the antioxidant activity of pasta (ABTS, DPPH, FRAP, and ORAC (oxygen radical absorbance capacity) assays) in both raw and cooked pasta products. The cooking process increased the content of phenolic compounds from 3.5\% (control sample) to $26.2 \%$ (pasta with $55 \%$ amaranth flour and $5 \%$ amaranth leaves). Moreover, the addition of amaranth leaves enriched pasta with iron, zinc, magnesium, potassium, and fibre. Additionally, the enriched pasta exhibited decreased optimum cooking time and increased cooking loss due to the reduction in gluten content and inhibition of gluten development. Alemayehu et al. [82] enriched wheat pasta with dried and powdered nettle (Urtica simensis) leaves. The leaves of this plant have high nutritional value, with high content of protein, carbohydrates, and minerals [83]. The replacement of wheat flour with dried nettle leaves at a $20 \%$ level increased the content of protein (from $9.9 \%$ to $13.4 \%$ ), ash (from $0.73 \%$ to $2.66 \%$ ), and DF (from $0.48 \%$ to $2.65 \%$ ) in the enriched pasta as compared to that in the control sample. Importantly, the content of iron, zinc, and calcium in particular also significantly increased in the fortified product. Parsley leaves are an interesting additive in pasta production. Sęczyk et al. [84] studied the effect of the addition of powdered parsley leaves on the nutraceutical and nutritional potential of durum wheat pasta. They found that parsley-enriched pasta showed a higher content of phenolics and increased antioxidant activity (ABTS and FRAP assays). This tendency was also observed after the in vivo digestion of pasta, and the enriched pasta showed high bioaccessibility of phenolics. The incorporation of parsley leaves into the wheat sample did not significantly influence starch digestibility, but significantly decreased protein digestibility (a decrease of approximately $20 \%$ for pasta with addition of $4 \%$ parsley). Another study [85] investigated the effect of the addition of dried and powdered leaves of Pereskia aculeata Miller on the properties of common wheat pasta. The leaves of this vegetable are a rich source of protein, fibre, minerals, and vitamins [86]. As compared to the control product, the incorporation of this additive at $10 \%$ and $20 \%$ proportions relative to wheat flour led to a threefold and fivefold increase, respectively, in fibre content in the enriched pasta. Furthermore, the enriched pasta showed a significant increase in calcium and iron content. It is worth emphasising here that cooking loss decreased after the incorporation of $P$. aculeate leaves into pasta. The firmness and sensory quality of pasta, however, decreased remarkably when wheat flour was replaced with $20 \%$ of leaves.

On the basis of the abovementioned studies, the fortification of pasta with herbs and leaves of different plants is an interesting trend that results in obtaining a functional product with an enhanced level of bioactive compounds and with good sensory quality (Table 4). 
Table 4. Influence of addition of herbs and different parts of plants on wheat pasta properties.

\begin{tabular}{|c|c|c|c|}
\hline $\begin{array}{l}\text { Main Raw Materials and } \\
\text { Replacement Level }\end{array}$ & $\begin{array}{l}\text { Method of Pasta Production } \\
\text { and Drying Conditions }\end{array}$ & $\begin{array}{c}\text { Main Effect and Recommended Level of } \\
\text { Additive }\end{array}$ & References \\
\hline $\begin{array}{l}\text { Common wheat flour, eggs } \\
\text { and leaves of Pereskia culeate } \\
(10 \text { and } 20 \%)\end{array}$ & $\begin{array}{l}\text { The dough was laminated, } \\
\text { sheets were cut into pasta form, } \\
\text { pasta was dried at } 60^{\circ} \mathrm{C} \text { for } \\
40 \mathrm{~min}\end{array}$ & $\begin{array}{l}\text { Enriched pasta in dietary fibre, calcium, and } \\
\text { iron; improved cooking and sensory quality of } \\
\text { pasta. The recommended level of Pereskia } \\
\text { culeate leaves: } 10 \%\end{array}$ & [85] \\
\hline $\begin{array}{l}\text { Semolina and Salicornia } \\
\text { europaea extract (concentration } \\
\text { of extracting solvent } 40 \% \\
(v / v) \text {, ethanol and ratio of } \\
1: 30(w / v))\end{array}$ & $\begin{array}{l}\text { The dough was laminated to } \\
\text { obtain sheets and shaped into } \\
\text { tagliatelle (strands } 1 \mathrm{~cm} \text { width } \\
\text { and } 3 \mathrm{~mm} \text { thickness) }\end{array}$ & $\begin{array}{l}\text { Enrichment of pasta in phenols and flavonoids, } \\
\text { enhanced antioxidant activity. The } \\
\text { recommended level of proposed additive was } \\
\text { not determined }\end{array}$ & [74] \\
\hline $\begin{array}{l}\text { Common wheat flour and } \\
\text { powdered leaves of Cistus } \\
\text { incanus L. }(1,2,3,4 \text {, and } 5 \%)\end{array}$ & $\begin{array}{l}\text { The dough was extruded for } \\
\text { spaghetti with } 2 \mathrm{~mm} \text { diameter; } \\
\text { pasta was dried at } 22{ }^{\circ} \mathrm{C} \text { for } 24 \mathrm{~h}\end{array}$ & $\begin{array}{l}\text { Enhanced AA of pasta and increased level of } \\
\text { TPC phenolics. The recommended level of } \\
\text { Cistus incanus is up to } 3 \%\end{array}$ & [76] \\
\hline $\begin{array}{l}\text { Semolina and Moringa oleifera } \\
\text { L. leaf powder }(5,10, \\
\text { and } 15 \%)\end{array}$ & $\begin{array}{l}\text { The dough was extruded } \\
\text { through a } 0.22 \mathrm{~cm} \text { diameter } \\
\text { spaghetti die }\end{array}$ & $\begin{array}{l}\text { Enhanced pasta in minerals and TPC, } \\
\text { increased antioxidant activity. The } \\
\text { recommended level of Moringa oleifera leaf } \\
\text { powder is up to } 15 \%\end{array}$ & [80] \\
\hline $\begin{array}{l}\text { Semolina and mixture of } \\
\text { amaranth leaves with } \\
\text { amaranth seed flour (sixteen } \\
\text { different formulations) }\end{array}$ & $\begin{array}{l}\text { The dough was extruded } \\
\text { through and dried at } 80^{\circ} \mathrm{C} \text { for } \\
4 \mathrm{~h}\end{array}$ & $\begin{array}{l}\text { Enhanced pasta in minerals and phenolics, } \\
\text { increased AA. Pasta with } 35 \% \text { of amaranth } \\
\text { flour and } 4 \% \text { dried amaranth leaves } \\
\text { was recommended }\end{array}$ & [81] \\
\hline $\begin{array}{l}\text { Semolina and dried nettle } \\
\text { (Urtica simensis) leaves }(5,10, \\
15 \text {, and } 20 \%)\end{array}$ & $\begin{array}{l}\text { The dough was laminated up to } \\
\text { a } 2 \mathrm{~mm} \text { thickness of pasta. }\end{array}$ & $\begin{array}{l}\text { Increased level of protein, minerals, and fibre } \\
\text { in fortified pasta. The recommended level of } \\
\text { nettle powder is up to } 15 \%\end{array}$ & [82] \\
\hline $\begin{array}{l}\text { Semolina and dried parsley } \\
\text { leaves }(1,2,3 \text {, and } 4)\end{array}$ & $\begin{array}{l}\text { The dough was extruded and } \\
\text { dried at } 40{ }^{\circ} \mathrm{C} \text { until pasta } \\
\text { reached } 12 \% \text { of moisture }\end{array}$ & $\begin{array}{l}\text { Parsley-enriched pasta was characterised by } \\
\text { higher content of TPC and increased AA. } \\
\text { Phenolics from enriched pasta were highly } \\
\text { bioaccessible. Incorporation of parsley leaves } \\
\text { significantly decreased protein digestibility of } \\
\text { pasta. The recommended level of proposed } \\
\text { additive was not determined }\end{array}$ & [84] \\
\hline
\end{tabular}

AA—antioxidant activity, TPC—-total phenolic content.

\section{Pasta Enriched with Raw Materials Rich in DF}

DF is defined as the "edible parts of plants or analogues of carbohydrates that are resistant to digestion and absorption in the human small intestine with complete or partial fermentation in the large intestine" [87]. DF plays a very important role in the human body. The lack of DF in the diet often leads to gastrointestinal diseases and increased risk of cardiovascular diseases [88]. The consumption of high-fibre foods contributes to a reduction in blood pressure [89] and cholesterol levels [90] and is associated with a lower risk of obesity [91]. The recommended level of total DF intake depends on sex and age and ranges from 21 to $38 \mathrm{~g}$ per day [87]. The development of fibre-rich pasta allows products with health-promoting properties to be obtained. Thus, for the past several years, much attention has been focused on the possibility of enriching pasta with DF of various origins [92-94]. This trend continues even today. Recently, Garbata et al. [35] studied the quality and nutritional characteristics of pasta enriched with inulin (fructose polymers classified as a highly water-soluble fibre) with a high and low degree of polymerisation from cardoon roots and chicory, respectively. The incorporation of both types of inulin into pasta decreased its cooking time. The inulin extracted from cardoon was released to a higher extent in the digestive tract than that extracted from chicory. Additionally, the inulin from cardoon did not modify the sensory properties of pasta. This can be explained by the fact that inulin from cardoon shows greater resistance to the hydrolytic activity of the enzymes in the upper human digestive tract. Simonato et al. [95] added 
oil pomace to durum wheat pasta. Oil pomace is an industrial by-product obtained after the extraction of olive and contains around $48 \%$ DF [95]. The increased content of this additive in pasta significantly influenced the rate of starch digestibility. A decrease in the content of rapidly digestible starch and an increase in the content of slowly digestible starch and resistant starch were observed. Both cooked and uncooked fibre-rich pasta showed a higher content of total phenolics and higher antioxidant activity (DPPH and ABTS assays) than control samples. However, the cooking process drastically decreased the total phenolic content (approximately 70\%) and the antioxidant activity of both control and enriched pasta. Moreover, oil pomace addition decreased the lightness and yellowness of pasta, but increased its redness. Pasta fortification also altered the cooking properties and texture of the product. The enriched pasta required a shorter cooking time but exhibited higher cooking loss and higher water absorption. Additionally, the fortification of pasta increased its firmness and adhesiveness. These changes were caused by the modification of the pasta structure by the fibre addition. Biernacka et al. [96] partially replaced wheat flour with carob fibre. Carob fibre is a by-product of carob syrup processing and contains mainly insoluble DF with a high content of polyphenols [97]. The authors found that carob fibre addition increased the total phenolic content and the antioxidant activity of common wheat pasta (FRAP, ABTS, CHEL, and LOX (lipoxygenase activity) assays). Moreover, after in vitro digestion, the phenolic content and the antioxidant activity of the enriched pasta increased several times. It is worth emphasising here that the addition of carob flour had little effect on the cooking quality of pasta, but decreased its lightness and redness. Additionally, Seeczyk et al. [98] reported that the incorporation of carob fibre into semolina pasta decreased both starch and protein digestibility. Piwińska et al. [99] used fibre-rich oat $\beta$-glucan flour to enrich durum wheat pasta. The oat flour contained $23 \%$ insoluble fraction of DF and $21 \%$ soluble fibre with $16 \% \beta$-glucan. The authors found that the additive had no significant influence on the optimum cooking time of pasta, but increased the cooking loss, swelling index, and water uptake of pasta during cooking. The addition of $\beta$-glucan also strongly influenced the texture of pasta and decreased its firmness and adhesiveness. Moreover, the content of DF increased from approximately $2 \%$ in control pasta to approximately $18 \%$ in pasta with $20 \%$ DF. Other authors [100] replaced durum wheat pasta with oat powder containing $80 \%$ insoluble fibre. A similar influence on pasta quality was noted for pasta enriched with fibre-rich oat $\beta$-glucan [99]. Pasta with 20\% insoluble fibre increased the DF content by sevenfold as compared to that in the control product. Additionally, the authors found that a higher reduction of oat powder particles resulted in pasta with better quality [100]. Padalino et al. [101] produced durum wheat pasta enriched with tomato peels. This processing residue contains approximately $84 \%$ $\mathrm{DF}$, with a major fraction of insoluble DF (approximately 72\%). It is also rich in rutin and carotenoids [102]. The incorporation of tomato peel enriched spaghetti with lycopene and $\beta$-carotene. The soluble and insoluble fibre content in the fortified pasta also increased as compared to that in control pasta. This additive, however, had a negative influence on pasta sensory quality due to the unpleasant odour, decreased elasticity, and increased hardness. Marinelli et al. [103] used red grape marc, a by-product of winemaking, as a pasta ingredient to improve the nutritional value of the final product. Grape marc is a rich source of DF (usually above 70\%) with excellent antioxidant properties [104]. Enrichment of pasta with this by-product increased the content of phenolics and anthocyanins and the antioxidant activity (FRAP assay) in both raw and cooked pasta as compared to that in the control product. The cooking process had no negative influence on either the phenolic content or the antioxidant capacity of pasta. Most importantly, the addition of grape marc to pasta increased the bioaccessibility of polyphenols and decreased the glycaemic index. However, this additive had a negative influence on the sensory properties of pasta. In particular, a reduction in firmness and elasticity and increase in adhesiveness were observed for the enriched pasta. An interesting study of pasta fortification with brewer's spent grain was conducted by Cappa and Cappa [105] and Nocente et al. [106]. Brewer's spent grain is rich in DF (approximately 70\%) and protein (approximately 20\%) and is a by-product 
generated in the beer-brewing process [107]. This additive increased the fibre content of pasta, especially the insoluble fraction, but it decreased the cooking quality because of higher starch granule swelling and weakening of the protein network [105]. Kim et al. [108] studied the effect of the addition of insoluble DF from kimchi by-product (approximately $73 \% \mathrm{DF}$ ) on the properties of pasta. Kimchi is a fermented dish prepared from a mixture of vegetables (cabbage, radish, and red pepper as the main ingredients), with many health properties [109]. On the basis of cooking quality and sensory acceptance, the authors found that the proportion of this by-product in semolina pasta should not exceed $2 \%$. The addition of this component at a higher proportion increased cooking loss and led to lower scores for texture, flavour, and taste. Michalak-Majewska et al. [94] enriched wheat pasta with dried and powdered onion skin. Onion skin is a valuable source of many pro-health compounds such as DF, fructan, fructo-oligosaccharides, quercetin, and minerals [110]. The total DF content in the enriched pasta ( $7.5 \%$ of onion skin) increased by approximately twofold as compared to that in the control sample, while the content of carbohydrates, protein, and fat decreased. Consequently, the energetic value of the enriched pasta decreased. The incorporation of onion skin in pasta increased both the total phenolic content and total flavonoid content. Consequently, the antioxidant activity (DPPH and FRAP assays) also increased. Interestingly, the content of these compounds did not decrease after pasta cooking; moreover, the cooking process enhanced the antioxidant activity of pasta because of the release of some phenolic acids during hydrothermal treatment. However, the enrichment of pasta with powdered onion skin decreased its cooking quality and sensory value. The lightness and yellowness of both raw and cooked pasta decreased, whereas redness increased with the increase in the percentage of onion powder in the pasta recipe.

On the basis of the above information, it can be concluded that enriching pasta with fibre-rich by-products from the food industry is a current trend. The incorporation of such raw materials into wheat flour or semolina increases the content of bioactive compounds in pasta and enhances its antioxidant activity, which further increases the pro-health value of pasta (Table 5). This type of food fortification also has a positive influence on waste reduction. On the other hand, the use of such materials can have a negative effect on consumers' acceptability. Additionally, fiber can especially negatively affect the quality of pasta if not properly distributed [111].

Table 5. Effect of pasta fortification with different raw materials rich in DF.

\begin{tabular}{lll}
\hline $\begin{array}{l}\text { Main Raw Materials and } \\
\text { Replacement Level }\end{array}$ & $\begin{array}{l}\text { Method of Pasta Production } \\
\text { and Drying Conditions }\end{array}$ & $\begin{array}{l}\text { Main Effect and Recommended Level of } \\
\text { Additive }\end{array}$ \\
\hline & $\begin{array}{l}\text { Pasta was extruded as } \\
\text { Vermicelli with around } 3.0 \mathrm{~mm}\end{array}$ & $\begin{array}{l}\text { Increased TPC and AA. Positive influence on } \\
\text { sensory attributes and cooking quality of pasta. } \\
\text { common wheat pasta and }\end{array}$ \\
$\begin{array}{ll}\text { thickness, } 80 \mathrm{~mm} \text { length and } \\
\text { dried at } 50^{\circ} \mathrm{C}\end{array}$ & $\begin{array}{l}\text { Thecommended level of carob fibre is up } \\
\text { to } 4 \%\end{array}$ \\
\hline
\end{tabular}

Semolina and soft wheat flour (1:1), egg powder up to $12 \%$, brewer's spent grains from 3 to $25 \%$

Pasta was laminated and fresh lasagna sheets were produced Increased fibre content in pasta but decreased

(spaghetti $2 \mathrm{~mm}$ diameter) Pasta was air-dried at $50{ }^{\circ} \mathrm{C}$ cooking quality. The calculated optimal level of flour form brewer's spent grains is $6.2 \%$

Increased TPC and AA. Decreased content of rapidly digestible starch and increase in content of slowly digestible starch. The recommended level of proposed additive was not determined

[105] Increased TPC, TFC, and AA. Decreased the caloric value of pasta. The recommended level [94] of onion skin powder is up to $2.5 \%$
Semolina and onion skin powder $(2.5,5.7,5.0$, and $10 \%)$
The dough was extruded and dried at $35-55{ }^{\circ} \mathrm{C}$ and a humidity level of $85-55 \%$ 
Table 5. Cont.

\begin{tabular}{|c|c|c|c|}
\hline $\begin{array}{l}\text { Main Raw Materials and } \\
\text { Replacement Level }\end{array}$ & $\begin{array}{l}\text { Method of Pasta Production } \\
\text { and Drying Conditions }\end{array}$ & $\begin{array}{l}\text { Main Effect and Recommended Level of } \\
\text { Additive }\end{array}$ & References \\
\hline \multirow[b]{2}{*}{$\begin{array}{l}\text { Semolina and oat dietary fibre } \\
\text { rich in } \beta \text {-glucan }(4,8,12,16 \text {, } \\
\text { and } 20 \%)\end{array}$} & $\begin{array}{l}\text { The dough was extruded and } \\
\text { dried in two ways: }\end{array}$ & \multirow[b]{2}{*}{$\begin{array}{l}\text { Increased fibre content in pasta. Negative } \\
\text { influence on pasta cooking quality and texture. } \\
\text { The recommended level of proposed additive } \\
\text { was not determined }\end{array}$} & \multirow[b]{2}{*}{ [99] } \\
\hline & $\begin{array}{l}\text { (1) Air drying: for } 10 \mathrm{~min} \text { at } \\
80{ }^{\circ} \mathrm{C} \text {, for } 40 \mathrm{~min} \text { at } 94{ }^{\circ} \mathrm{C} \\
(37 \% \mathrm{RH}) \text {, and for } 180 \mathrm{~min} \\
\text { at } 80^{\circ} \mathrm{C} \text { and }(69 \% \mathrm{RH}) \text {. } \\
\text { (2) Vacuum drying: at } 80^{\circ} \mathrm{C} \text {, } \\
15 \mathrm{kPa} \text { for } 180 \mathrm{~min}\end{array}$ & & \\
\hline
\end{tabular}

The dough was extruded and

dried in two ways:

(1) Air drying: for $10 \mathrm{~min}$ at

Semolina and insoluble oat dietary fibre (10 and $20 \%$ ) $80^{\circ} \mathrm{C}$, for $45 \mathrm{~min}$ at $60^{\circ} \mathrm{C}$, for $45 \mathrm{~min}$ at $65^{\circ} \mathrm{C}$, and $75 \mathrm{~min}$ at $62{ }^{\circ} \mathrm{C}$.

(2) Vacuum drying: at $80^{\circ} \mathrm{C}$

Increased fibre content in pasta. Negative influence on pasta cooking quality and texture. The recommended level of proposed additive [100] is $10 \%$ at three $60 \mathrm{~min}$ cycles, 50 , 30 , and $10 \mathrm{kPa}$ for $180 \mathrm{~min}$
The dough was extruded and dried in five steps:

Wholemeal semolina and tomato peel (10 and 15\%)

(1) $20 \mathrm{~min}$ at $60^{\circ} \mathrm{C}, \mathrm{RH} 65 \%$

(2) $130 \mathrm{~min}$ at $90^{\circ} \mathrm{C}, \mathrm{RH} 79 \%$

(3) $150 \mathrm{~min}$ at $75^{\circ} \mathrm{C}$, RH $78 \%$

(4) $160 \mathrm{~min}$ at $45^{\circ} \mathrm{C}$, RH $63 \%$

(5) $1040 \mathrm{~min}$ at $50{ }^{\circ} \mathrm{C}, \mathrm{RH} 50 \%$
Increased content of dietary fibre and carotenoids (lycopene and $\beta$-carotene) and dietary fibre. The recommended level of proposed additive was not determined
The dough was extruded and dried in five steps:
(1) $20 \mathrm{~min}$ at $55^{\circ} \mathrm{C}$,
(2) $580 \mathrm{~min}$ at $75^{\circ} \mathrm{C}$,
(3) $40 \mathrm{~min}$ at $60^{\circ} \mathrm{C}$,
(4) 200 min at $45^{\circ} \mathrm{C}$,
(5) $840 \mathrm{~min}$ at $40^{\circ} \mathrm{C}$

$\begin{array}{ll}\text { Semolina and grape marc } & \text { (2) } 580 \mathrm{~min} \text { at } 75^{\circ} \mathrm{C} \text {, } \\ \text { flour }(15 \%) & \text { (3) } 40 \mathrm{~min} \text { at } 60^{\circ} \mathrm{C} \text {, } \\ & \text { (4) } 200 \mathrm{~min} \text { at } 45^{\circ} \mathrm{C} \text {, } \\ & \text { (5) } 840 \mathrm{~min} \text { at } 40^{\circ} \mathrm{C}\end{array}$

Fresh pasta (short-cut pasta, "little ears" shape) was produced manually
Increased TPC, anthocyanin content and AA. Increased bioaccessibility of polyphenols and decreased amount glycaemic load. The recommended level of proposed additive was not determined
Increased TPC and AA. Did not have negative influence on pasta cooking properties and texture. The recommended level of extract was artichoke canning by-products (55 mL/100 g) not determined

AA—antioxidant activity, TPC—-total phenolic content, TFC—total flavonoid content.

\section{Conclusions}

Pasta, similar to bread, is an excellent and easy-to-use food for fortification. Recently, pasta has been the subject of many food fortification strategies to improve its nutritional value and functional properties. The incorporation of different plant and animal raw materials into pasta can be a very attractive alternative for consumers who prefer healthy food. Pasta formulations with animal raw materials such as powdered fish or insects increased the content of protein and polyunsaturated fatty acids. Furthermore, the addition of different parts of plants, such as fruits, vegetables, or seeds, into pasta improved the content of bioactive compounds and increased its antioxidant capacity (Figure 2). The incorporation of industry by-products into pasta can also result in the reduction of pollution and significantly improve the nutritional value, particularly for pasta enriched with fibre and phenolic compounds. Additionally, the incorporation of fibre-rich raw materials into pasta increases the content of slowly digestible carbohydrates and decreases the glycaemic index. Such methods of determination of antioxidant activity assays as DPPH, ABTS, and FRAP confirm that the incorporation into pasta of different plant materials increases 
its antioxidant capacity. Enriched pasta, however, is often characterised by increased cooking loss and decreased sensory scores due to decreased firmness, colour changes, and unacceptable taste or smell. Therefore, obtaining a fortified pasta product with acceptable quality is often a challenge, and the proportion of individual additives should be precisely determined considering the preferences of consumers. The effect of pasta fortification and factors influencing consumers' acceptance of pasta are presented in Figure 2.

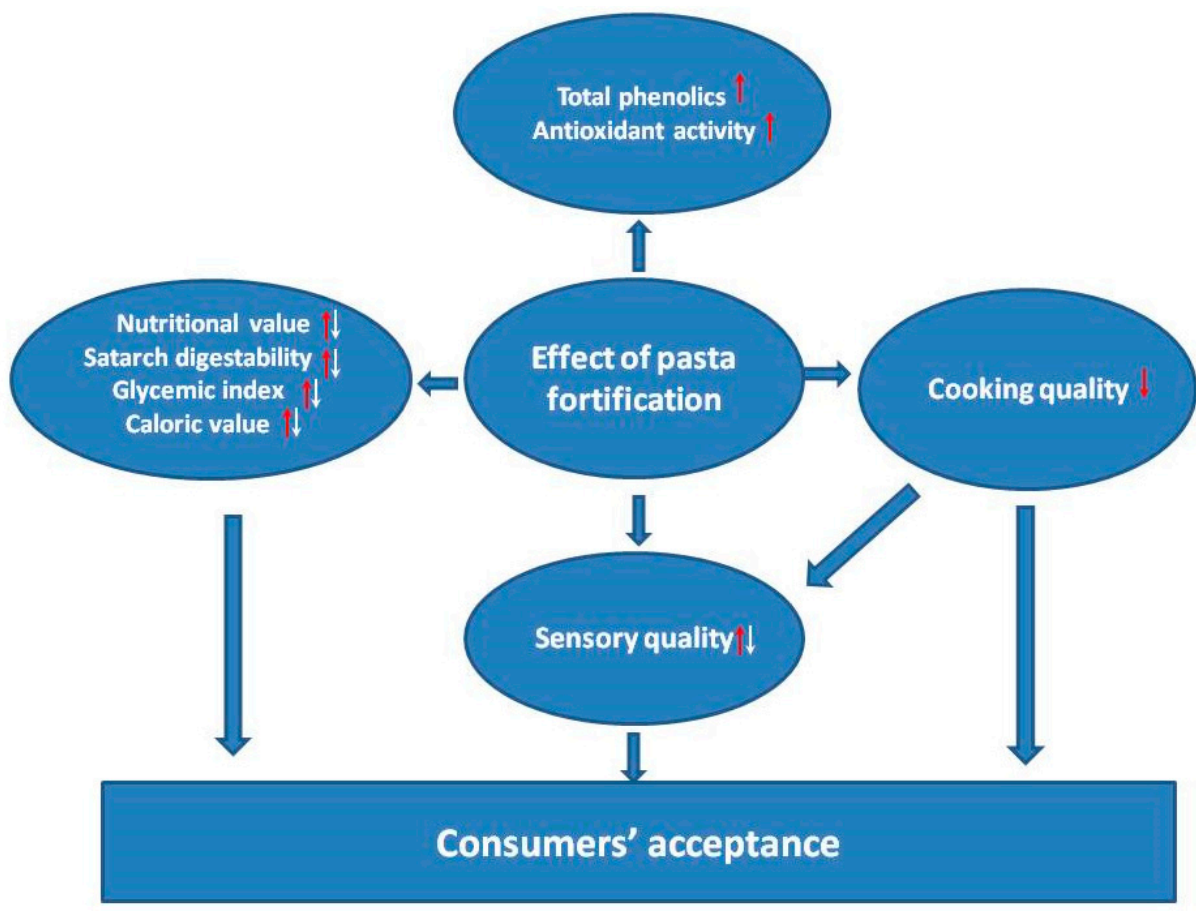

Figure 2. Effect of pasta fortification and factors influencing consumers' acceptance of pasta.

In particular, such additives as dried blackberry, raspberry, black and red currant powder, grape pomace, powdered whey, and beef emulsion increased both the nutritional value and antioxidant activity of pasta without a negative influence on consumer acceptance.

Funding: This research received no external funding.

Institutional Review Board Statement: Not applicable.

Informed Consent Statement: Not applicable.

Data Availability Statement: Not applicable.

Conflicts of Interest: The author declares no conflict of interest.

\section{References}

1. Nilusha, R.A.T.; Jayasinghe, J.M.J.K.; Perera, O.D.A.N.; Perera, P.I.P. Development of pasta products with nonconventional ingredients and their effect on selected quality characteristics: A brief overview. Int. J. Food Sci. 2019, 2019, 1-10. [CrossRef]

2. Bustos, M.C.; Perez, G.T.; Leon, A.E. Structure and quality of pasta enriched with functional ingredients. RSC Adv. 2015, 5, 30780-30792. [CrossRef]

3. Fuad, T.; Prabhasankar, P. Role of ingredients in pasta product quality: A review on recent developments. Crit. Rev. Food Sci. Nutr. 2010, 50, 787-798. [CrossRef]

4. Lucas-González, R.; Ángel Pérez-Álvarez, J.; Moscaritolo, S.; Fernández-López, J.; Sacchetti, G.; Viuda-Martos, M. Evaluation of polyphenol bioaccessibility and kinetic of starch digestion of spaghetti with persimmon (Dyospyros kaki) flours coproducts during in vitro gastrointestinal digestion. Food Chem. 2021, 338, 128142. [CrossRef] [PubMed]

5. Gutiérrez-Grijalva, E.P.; Ambriz-Pére, D.L.; Leyva-López, N.; Castillo-López, R.I.; Heredia, J.B. Review: Dietary phenolic compounds, health benefits and bioaccessibility. Arch. Latinoam. Nutr. 2016, 66, 87-100.

6. Panghal, A.; Kaur, R.; Janghu, S.; Sharma, P.; Sharma, P.; Chhikara, N. Nutritional, phytochemical, functional and sensorial attributes of Syzygium cumini L. pulp incorporated pasta. Food Chem. 2019, 289, 723-728. [CrossRef] 
7. Oyeyinka, S.A.; Adepegba, A.A.; Oyetunde, T.T.; Oyeyinka, A.T.; Olaniran, A.F.; Iranloye, Y.M.; Olagunju, O.F.; Manley, M.; Kayitesi, E.; Njobeh, P.B. Chemical, antioxidant and sensory properties of pasta from fractionated whole wheat and Bambara groundnut flour. LWT Food Sci. Technol. 2020, 138, 110618. [CrossRef]

8. Loi, M.; Paciolla, C.; Logrieco, A.F.; Mulè, G. Plant bioactive compounds in pre- and postharvest management for aflatoxins reduction. Front. Microbiol. 2020, 11, 243. [CrossRef]

9. Melini, V.; Melini, F.; Acquistucci, R. Phenolic compounds and bioaccessibility thereof in functional pasta. Antioxidants 2020, 9, 343. [CrossRef]

10. Zhang, Y.J.; Gan, R.Y.; Li, S.; Zhou, Y.; Li, A.N.; Xu, D.P.; Li, H.B.; Kitts, D.D. Antioxidant phytochemicals for the prevention and treatment of chronic diseases. Molecules 2015, 20, 21138-21156. [CrossRef]

11. Cory, H.; Passarelli, S.; Szeto, J.; Tamez, M.; Mattei, J. The Role of Polyphenols in Human Health and Food Systems: A Mini-Review. Front. Nutr. 2018, 5, 87. [CrossRef] [PubMed]

12. Wojtunik-Kulesza, K.; Oniszczuk, A.; Oniszczuk, T.; Combrzyński, M.; Nowakowska, D.; Matwijczuk, A. Influence of in vitro digestion on composition, bioaccessibility and antioxidant activity of food polyphenols-a non-systematic review. Nutrients $\mathbf{2 0 2 0}$ 12, 1401. [CrossRef]

13. Arts, I.C.; Hollman, P.C. Polyphenols and disease risk in epidemiologic studies. Am. J. Clin. Nutr. 2005, 81 (Suppl. S1), S317-S325. [CrossRef]

14. Duda, A.; Adamczak, J.; Chelminska, P.; Juszkiewicz, J.; Kowalczewski, P. Quality and nutritional/textural properties of durum wheat pasta enriched with cricket powder. Foods 2019, 8, 46. [CrossRef]

15. Ozgoren, E.; Yapar, A. Effect of the addition of smoked trout fillet powder to the quality properties of pasta. Ital. J. Food Sci. 2019, 31, 110-124.

16. Biernacka, B.; Dziki, D.; Gawlik-Dziki, U.; Różyło, R. Common wheat pasta enriched with cereal coffee: Quality and physical and functional properties. LWT Food Sci. Technol. 2020, 139, 110516. [CrossRef]

17. Zardetto, S.; Dalla Rosa, M. Study of the effect of lamination process on pasta by physical chemical determination and near infrared spectroscopy analysis. J. Food Eng. 2006, 74, 402-409. [CrossRef]

18. Teterycz, D.; Sobota, A.; Zarzycki, P.; Latoch, A. Legume flour as a natural colouring component in pasta production. J. Food Sci. Technol. 2020, 57, 301-309. [CrossRef]

19. Vimercati, W.C.; da Silva Araújo, C.; Macedo, L.L.; Maradini Filho, A.M.; Saraiva, S.H.; Teixeira, L.J.Q. Influence of drying temperature on drying kinetics, energy consumption, bioactive compounds and cooking quality of pasta enriched with spinach. J. Food Process. Eng. 2020, 43, e13571. [CrossRef]

20. Oliviero, T.; Fogliano, V. Food design strategies to increase vegetable intake: The case of vegetable enriched pasta. Trends Food Sci. Technol. 2016, 51, 58-64. [CrossRef]

21. Bustos, M.C.; Paesani, C.; Quiroga, F.; León, A.E. Technological and sensorial quality of berry-enriched pasta. Cereal Chem. 2019, 96, 967-976. [CrossRef]

22. Biernacka, B.; Dziki, D.; Różyło, R.; Gawlik-Dziki, U. Banana powder as an additive to common wheat pasta. Foods 2020, 9, 53. [CrossRef]

23. Zheng, Z.; Stanley, R.; Gidley, M.J.; Dhital, S. Structural properties and digestion of green banana flour as a functional ingredient in pasta. Food Funct. 2016, 7, 771-780. [CrossRef]

24. Butt, M.S.; Sultan, M.T.; Aziz, M.; Naz, A.; Ahmed, W.; Kumar, N.; Imran, M. Persimmon (Diospyros kaki) fruit: Hidden phytochemicals and health claims. EXCLI J. 2015, 14, 542-561. [PubMed]

25. Chusak, C.; Chanbunyawat, P.; Chumnumduang, P.; Chantarasinlapin, P.; Suantawee, T.; Adisakwattana, S. Effect of gac fruit (Momordica cochinchinensis) powder on in vitro starch digestibility, nutritional quality, textural and sensory characteristics of pasta. LWT Food Sci. Technol. 2020, 118, 108856. [CrossRef]

26. Tolve, R.; Pasini, G.; Vignale, F.; Favati, F.; Simonato, B. Effect of grape pomace addition on the technological, sensory, and nutritional properties of durum wheat pasta. Foods 2020, 9, 354. [CrossRef]

27. Minarovičová, L.; Lauková, M.; Kohajdová, Z.; Karovičová, J.; Dobrovická, D.; Kuchtová, V. Qualitative properties of pasta enriched with celery root and sugar beet by-products. Czech J. Food Sci. 2018, 36, 66-72. [CrossRef]

28. Bustos, M.C.; Ramos, M.I.; Pérez, G.T.; León, A.E. Utilization of kañawa (Chenopodium pallidicaule aellen) flour in pasta making. J. Chem. 2019, 2019, 4385045. [CrossRef]

29. Pasqualone, A.; Punzi, R.; Trani, A.; Summo, C.; Paradiso, V.M.; Caponio, F.; Gambacorta, G. Enrichment of fresh pasta with antioxidant extracts obtained from artichoke canning by-products by ultrasound-assisted technology and quality characterisation of the end product. Int. J. Food Sci. Technol. 2017, 52, 2078-2087. [CrossRef]

30. Djeukeu, W.A.; Gouado, I.; Leng, M.S.; Vijaykrishnaraj, M.; Prabhasankar, P. Effect of dried yam flour (Dioscorea schimperiana) on cooking quality, digestibility profile and antioxidant potential of wheat based pasta. J. Food Meas. Charact. 2017, 11, 1421-1429. [CrossRef]

31. Kolarič, L.; Minarovičová, L.; Lauková, M.; Karovičová, J.; Kohajdová, Z. Pasta noodles enriched with sweet potato starch: Impact on quality parameters and resistant starch content. J. Texture Stud. 2020, 51, 464-474. [CrossRef] [PubMed]

32. Vital, A.C.P.; Itoda, C.; Crepaldi, Y.S.; Saraiva, B.R.; Matumoto-Pintro, P.T. Use of asparagus flour from non-commercial plants (residue) for functional pasta production: Asparagus flour for functional pasta production. J. Food Sci. Technol. 2020, 57, 2926-2933. [CrossRef] 
33. Ahmed, S.; Ahmed, K.S.; Hossain, M.S.; Azam, M.S.; Rahman, M.; Hoque, M.M. Proximate composition and antioxidant activity of syzygium cumini fruit grown at different regions in Bangladesh. Food Res. 2020, 4, 1693-1699. [CrossRef]

34. Rekha, M.N.; Chauhan, A.S.; Prabhasankar, P.; Ramteke, R.S.; Venkateswara Rao, G. Influence of vegetable purees on quality attributes of pastas made from bread wheat (T. aestivum). CYTA J. Food 2013, 11, 142-149. [CrossRef]

35. Garbetta, A.; D'Antuono, I.; Melilli, M.G.; Sillitti, C.; Linsalata, V.; Scandurra, S.; Cardinali, A. Inulin enriched durum wheat spaghetti: Effect of polymerization degree on technological and nutritional characteristics. J. Funct. Foods 2020, 71, 104004. [CrossRef]

36. Littardi, P.; Paciulli, M.; Carini, E.; Rinaldi, M.; Rodolfi, M.; Chiavaro, E. Quality evaluation of chestnut flour addition on fresh pasta. LWT Food Sci. Technol. 2020, 126, 109303. [CrossRef]

37. Gupta, A.; Sharma, S.; Reddy Surasani, V.K. Quinoa protein isolate supplemented pasta: Nutritional, physical, textural and morphological characterization. LWT Food Sci. Technol. 2021, 135, 110045. [CrossRef]

38. Huamaní, F.; Tapia, M.; Portales, R.; Doroteo, V.; Ruiz, C.; Rojas, R. Proximate analysis, phenolics, betalains, and antioxidant activities of three ecotypes of kaÑiwa (Chenopodium pallidicaule aellen) from peru. Pharmacologyonline 2020, 1, 229-236.

39. Makhlouf, S.; Jones, S.; Ye, S.H.; Sancho-Madriz, M.; Burns-Whitmore, B.; Li, Y.O. Effect of selected dietary fibre sources and addition levels on physical and cooking quality attributes of fibre-enhanced pasta. Food Qual. Saf. 2019, 3, 117-127. [CrossRef]

40. Cankurtaran, T.; Bilgiçli, N. Influence of wheat milling by-products on some physical and chemical properties of filled and unfilled fresh pasta. J. Food Sci. Technol. 2019, 56, 2845-2854. [CrossRef] [PubMed]

41. Parizad, P.A.; Marengo, M.; Bonomi, F.; Scarafoni, A.; Cecchini, C.; Pagani, M.A.; Marti, A.; Iametti, S. Bio-functional and structural properties of pasta enriched with a debranning fraction from purple wheat. Foods 2020, 9, 163. [CrossRef] [PubMed]

42. Sethi, S.; Nanda, S.K.; Bala, M. Quality assessment of pasta enriched with anthocyanin-rich black rice bran. J. Food Process. Preserv. 2020, 44. [CrossRef]

43. Alzuwaid, N.T.; Laddomada, B.; Fellows, C.M.; Egan, N.; Sissons, M. Supplementation of durum wheat spaghetti with wheat bran protein concentrate: Impacts on phytochemical profile and starch digestion. Cereal Chem. 2021, 98, 642-650. [CrossRef]

44. Baeza, G.; Sarriá, B.; Bravo, L.; Mateos, R. Polyphenol content, in vitro bioaccessibility and antioxidant capacity of widely consumed beverages. J. Sci. Food Agric. 2018, 98, 1397-1406. [CrossRef] [PubMed]

45. Zarzycki, P.; Sykut-Domańska, E.; Sobota, A.; Teterycz, D.; Krawęcka, A.; Blicharz-Kania, A.; Andrejko, D.; Zdybel, B. Flaxseed enriched pasta-Chemical composition and cooking quality. Foods 2020, 9, 404. [CrossRef]

46. Aranibar, C.; Pigni, N.B.; Martinez, M.; Aguirre, A.; Ribotta, P.; Wunderlin, D.; Borneo, R. Utilization of a partially-deoiled chia flour to improve the nutritional and antioxidant properties of wheat pasta. LWT Food Sci. Technol. 2018, 89, 381-387. [CrossRef]

47. Pigni, N.B.; Aranibar, C.; Lucini Mas, A.; Aguirre, A.; Borneo, R.; Wunderlin, D.; Baroni, M.V. Chemical profile and bioaccessibility of polyphenols from wheat pasta supplemented with partially-deoiled chia flour. LWT Food Sci. Technol. 2020, 124, 109134. [CrossRef]

48. Nunes, S.; Madureira, A.R.; Campos, D.; Sarmento, B.; Gomes, A.M.; Pintado, M.; Reis, F. Therapeutic and nutraceutical potential of rosmarinic acid-Cytoprotective properties and pharmacokinetic profile. Crit. Rev. Food Sci. Nutr. 2017, 57, 1799-1806. [CrossRef] [PubMed]

49. Teterycz, D.; Sobota, A.; Przygodzka, D.; Lysakowska, P. Hemp seed (Cannabis sativa L.) enriched pasta: Physicochemical properties and quality evaluation. PLoS ONE 2021, 16, e248790. [CrossRef]

50. Hidalgo, A.; Alamprese, C.; Marti, A.; Galli, S.; Terno, A.B.; Brandolini, A. Nutritional and technological properties of nontraditional einkorn (Triticum monococcum) wheat pasta. LWT Food Sci. Technol. 2020, 133, 109932. [CrossRef]

51. Hidalgo, A.; Brandolini, A. Kinetics of carotenoids degradation during the storage of einkorn (Triticum monococcum L. ssp. monococcum) and bread wheat (Triticum aestivum L. ssp. aestivum) flours. J. Agric. Food Chem. 2008, 56, 11300-11305. [CrossRef]

52. Hidalgo, A.; Brandolini, A. Nutritional properties of einkorn wheat (Triticum monococcum L.). J. Sci. Food Agric. 2014, 94, 601-612. [CrossRef]

53. Brandolini, A.; Lucisano, M.; Mariotti, M.; Hidalgo, A. A study on the quality of einkorn (Triticum monococcum L. ssp. monococcum) pasta. J. Cereal Sci. 2018, 82, 57-64. [CrossRef]

54. Pasini, G.; Greco, F.; Cremonini, M.A.; Brandolini, A.; Consonni, R.; Gussoni, M. Structural and Nutritional Properties of Pasta from Triticum monococcum and Triticum durum Species. A Combined 1H NMR, MRI, and Digestibility Study. J. Agric. Food Chem. 2015, 63, 5072-5082. [CrossRef]

55. Nocente, F.; Natale, C.; Galassi, E.; Taddei, F.; Gazza, L. Using einkorn and tritordeum brewers' spent grain to increase the nutritional potential of durum wheat pasta. Foods 2021, 10, 1-9. [CrossRef]

56. Coda, R.; Melama, L.; Rizzello, C.G.; Curiel, J.A.; Sibakov, J.; Holopainen, U.; Pulkkinen, M.; Sozer, N. Effect of air classification and fermentation by Lactobacillus plantarum VTT E-133328 on faba bean (Vicia faba L.) flour nutritional properties. Int. J. Food Microbiol. 2015, 193, 34-42. [CrossRef]

57. Rizzello, C.G.; Lorusso, A.; Montemurro, M.; Gobbetti, M. Use of sourdough made with quinoa (Chenopodium quinoa) flour and autochthonous selected lactic acid bacteria for enhancing the nutritional, textural and sensory features of white bread. Food Microbiol. 2016, 56, 1-13. [CrossRef] [PubMed]

58. Rizzello, C.G.; Verni, M.; Koivula, H.; Montemurro, M.; Seppa, L.; Kemell, M.; Katina, K.; Coda, R.; Gobbetti, M. Influence of fermented faba bean flour on the nutritional, technological and sensory quality of fortified pasta. Food Funct. 2017, 8, 860-871. [CrossRef] 
59. Lorusso, A.; Verni, M.; Montemurro, M.; Coda, R.; Gobbetti, M.; Rizzello, C.G. Use of fermented quinoa flour for pasta making and evaluation of the technological and nutritional features. LWT Food Sci. Technol. 2017, 78, 215-221. [CrossRef]

60. dos R. Goes, E.S.; de Souza, M.L.R.; Michka, J.M.G.; Kimura, K.S.; de Lara, J.A.F.; Delbem, A.C.B.; Gasparino, E. Fresh pasta enrichment with protein concentrate of tilapia: Nutritional and sensory characteristics. Food Sci. Technol. 2016, 36, 76-82. [CrossRef]

61. Pauter, P.; Różańska, M.; Wiza, P.; Dworczak, S.; Grobelna, N.; Sarbak, P.; Kowalczewski, P. Effects of the replacement of wheat flour with cricket powder on the characteristics of muffins. Acta Sci. Pol. Technol. Aliment. 2018, 17, $227-233$.

62. Jakab, I.; Tormási, J.; Dhaygude, V.; Mednyánszky, Z.S.; Sipos, L.; Szedljak, I. Cricket flour-laden millet flour blends' physical and chemical composition and adaptation in dried pasta products. Acta Aliment. 2020, 49, 4-12. [CrossRef]

63. Çabuk, B.; Yılmaz, B. Fortification of traditional egg pasta (erişte) with edible insects: Nutritional quality, cooking properties and sensory characteristics evaluation. J. Food Sci. Technol. 2020, 57, 2750-2757. [CrossRef]

64. Desai, A.; Brennan, M.A.; Brennan, C.S. The effect of semolina replacement with protein powder from fish (Pseudophycis bachus) on the physicochemical characteristics of pasta. LWT Food Sci. Technol. 2018, 89, 52-57. [CrossRef]

65. Monteiro, M.L.G.; Mársico, E.T.; Deliza, R.; Castro, V.S.; Mutz, Y.S.; Soares Junior, M.S.; Caliari, M.; dos Santos, E.A.; Conte-Junior, C.A. Physicochemical and sensory characteristics of pasta enriched with fish (Oreochromis niloticus) waste flour. LWT Food Sci. Technol. 2019, 111, 751-758. [CrossRef]

66. Reddy Surasani, V.K.; Singh, A.; Gupta, A.; Sharma, S. Functionality and cooking characteristics of pasta supplemented with protein isolate from pangas processing waste. LWT Food Sci. Technol. 2019, 111, 443-448. [CrossRef]

67. Singh, A.; Gupta, A.; Surasani, V.K.R.; Sharma, S. Influence of supplementation with pangas protein isolates on textural attributes and sensory acceptability of semolina pasta. J. Food Meas. Charact. 2021, 15, 1317-1326. [CrossRef]

68. Liu, T.; Hamid, N.; Kantono, K.; Pereira, L.; Farouk, M.M.; Knowles, S.O. Effects of meat addition on pasta structure, nutrition and in vitro digestibility. Food Chem. 2016, 213, 108-114. [CrossRef]

69. Jayawardena, S.R.; Morton, J.D.; Brennan, C.S.; Bekhit, A.E.D.A. Utilisation of beef lung protein powder as a functional ingredient to enhance protein and iron content of fresh pasta. Int. J. Food Sci. Technol. 2019, 54, 610-618. [CrossRef]

70. Foschia, M.; Peressini, D.; Sensidoni, A.; Brennan, M.A.; Brennan, C.S. How combinations of dietary fibres can affect physicochemical characteristics of pasta. Starch/Staerke 2015, 66, 41-46. [CrossRef]

71. Desai, A.S.; Brennan, M.A.; Brennan, C.S. Influence of semolina replacement with salmon (Oncorhynchus tschawytscha) powder on the physicochemical attributes of fresh pasta. Int. J. Food Sci. Technol. 2019, 54, 1497-1505. [CrossRef]

72. Cardoso Santiago, R.A.; Moreira-Araújo, R.S.R.; Pinto, E.; Silva, M.E.M.; Arêas, J.A.G. The potential of extruded chickpea, corn and bovine lung for malnutrition programs. Innov. Food Sci. Emerg. Technol. 2001, 2, 203-209. [CrossRef]

73. Boudalia, S.; Gueroui, Y.; Boumaza, B.; Bousbia, A.; Benada, M.; Leksir, C.; Mezroua, E.Y.; Zemmouchi, K.R.; Saoud, A.; Chemmam, M. Evaluation of physicochemical properties and sensory qualities of pasta enriched with freeze-dried sweet whey. Sci. Agric. Bohem. 2020, 51, 75-85.

74. Padalino, L.; Costa, C.; Del Nobile, M.A.; Conte, A. Extract of Salicornia europaea in fresh pasta to enhance phenolic compounds and antioxidant activity. Int. J. Food Sci. Technol. 2019, 54, 3051-3057. [CrossRef]

75. Kang, S.; Kim, D.; Lee, B.H.; Kim, M.R.; Hong, J.; Chiang, M. Antioxidant properties and cytotoxic effects of fractions from glasswort (Salicornia herbacea) seed extracts on human intestinal cells. Food Sci. Biotechnol. 2011, 20, 115-122. [CrossRef]

76. Lisiecka, K.; Wójtowicz, A.; Dziki, D.; Gawlik-Dziki, U. The influence of Cistus incanus L. leaves on wheat pasta quality. J. Food Sci. Technol. 2019, 56, 4311-4322. [CrossRef]

77. Cacak-Pietrzak, G.; Różyło, R.; Dziki, D.; Gawlik-Dziki, U.; Sułek, A.; Biernacka, B. Cistus incanus L. As an innovative functional additive to wheat bread. Foods 2019, 8, 349. [CrossRef]

78. Bathaie, S.Z. Saffron as a functional food and a nutraceutical using saffron and its constituents as the nutraceutics to protect against chronic diseases. In Proceedings of the IV International Symposium on Saffron Biology and Technology, Srinagar, India, 22-25 October 2012; Volume 1200, pp. 201-204.

79. Armellini, R.; Peinado, I.; Asensio-Grau, A.; Pittia, P.; Scampicchio, M.; Heredia, A.; Andres, A. In vitro starch digestibility and fate of crocins in pasta enriched with saffron extract. Food Chem. 2019, 283, 155-163. [CrossRef]

80. Simonato, B.; Tolve, R.; Rainero, G.; Rizzi, C.; Sega, D.; Rocchetti, G.; Lucini, L.; Giuberti, G. Technological, nutritional, and sensory properties of durum wheat fresh pasta fortified with Moringa oleifera L. leaf powder. J. Sci. Food Agric. 2020. [CrossRef]

81. Cárdenas-Hernández, A.; Beta, T.; Loarca-Piña, G.; Castaño-Tostado, E.; Nieto-Barrera, J.O.; Mendoza, S. Improved functional properties of pasta: Enrichment with amaranth seed flour and dried amaranth leaves. J. Cereal Sci. 2016, 72, 84-90. [CrossRef]

82. Alemayehu, D.; Desse, G.; Abegaz, K.; Desalegn, B.B.; Getahun, D. Proximate, mineral composition and sensory acceptability of homemade noodles from stinging nettle (Urtica simensis) leaves and wheat flour blends. Int. J. Food Sci. Nutr. Eng. 2016, 6, 55-61.

83. Bayba, K.B.; Dubale, A.A.; Mehari, B.; Atlabachew, M. Chemical composition of Urtica simensis grown in different regions of Ethiopia. J. Chem. 2020, 2020, 9546178. [CrossRef]

84. Sęczyk, Ł.; Świeca, M.; Gawlik-Dziki, U.; Luty, M.; Czyż, J. Effect of fortification with parsley (Petroselinum crispum Mill.) leaves on the nutraceutical and nutritional quality of wheat pasta. Food Chem. 2016, 190, 419-428. [CrossRef]

85. Sato, R.; de L. Cilli, L.P.; de Oliveira, B.E.; Maciel, V.B.V.; Venturini, A.C.; Yoshida, C.M.P. Nutritional improvement of pasta with Pereskia aculeata miller: A non-conventional edible vegetable. Food Sci. Technol. 2019, 39, 28-34. [CrossRef] 
86. Takeiti, C.Y.; Antonio, G.C.; Motta, E.M.P.; Collares-Queiroz, F.P.; Park, K.J. Nutritive evaluation of a non-conventional leafy vegetable (Pereskia aculeata Miller). Int. J. Food Sci. Nutr. 2009, 60, 148-160. [CrossRef]

87. Li, Y.O.; Komarek, A.R. Dietary fibre basics: Health, nutrition, analysis, and applications. Food Qual. Saf. 2017, 1, 47-59. [CrossRef]

88. Zinina, O.; Merenkova, S.; Tazeddinova, D.; Rebezov, M.; Stuart, M.; Okuskhanova, E.; Yessimbekov, Z.; Baryshnikova, N. Enrichment of meat products with dietary fibers: A review. Agron. Res. 2019, 17, 1808-1822.

89. Aleixandre, A.; Miguel, M. Dietary fiber and blood pressure control. Food Funct. 2016, 7, 1864-1871. [CrossRef]

90. Soliman, G.A. Dietary fiber, atherosclerosis, and cardiovascular disease. Nutrients 2019, 11, 1155. [CrossRef]

91. Ruhee, R.T. Dietary fiber and its effect on obesity: A review article. Adv. Med. Res. 2018, 1. [CrossRef]

92. Brennan, C.S. High-fibre pasta products. In Technology of Functional Cereal Products; Elsevier: Amsterdam, The Netherlands, 2007; pp. 428-445, ISBN 9781845691776.

93. Bustos, M.C.; Perez, G.T.; León, A.E. Sensory and nutritional attributes of fibre-enriched pasta. LWT Food Sci. Technol. 2011, 44, 1429-1434. [CrossRef]

94. Michalak-Majewska, M.; Teterycz, D.; Muszyński, S.; Radzki, W.; Sykut-Domańska, E. Influence of onion skin powder on nutritional and quality attributes of wheat pasta. PLoS ONE 2020, 15, e0227942. [CrossRef] [PubMed]

95. Simonato, B.; Trevisan, S.; Tolve, R.; Favati, F.; Pasini, G. Pasta fortification with olive pomace: Effects on the technological characteristics and nutritional properties. LWT Food Sci. Technol. 2019, 114, 108368. [CrossRef]

96. Biernacka, B.; Dziki, D.; Gawlik-Dziki, U.; Różyło, R.; Siastała, M. Physical, sensorial, and antioxidant properties of common wheat pasta enriched with carob fiber. LWT Food Sci. Technol. 2017, 77, 186-192. [CrossRef]

97. Ruiz-Roso, B.; Quintela, J.C.; de la Fuente, E.; Haya, J.; Pérez-Olleros, L. Insoluble carob fiber rich in polyphenols lowers total and ldl cholesterol in hypercholesterolemic sujects. Plant Foods Hum. Nutr. 2010, 65, 50-56. [CrossRef]

98. Sẹczyk, Ł.; Świeca, M.; Gawlik-Dziki, U. Effect of carob (Ceratonia siliqua L.) flour on the antioxidant potential, nutritional quality, and sensory characteristics of fortified durum wheat pasta. Food Chem. 2016, 194, 637-642. [CrossRef]

99. Piwińska, M.; Wyrwisz, J.; Kurek, M.; Wierzbicka, A. Effect of oat $\beta$-glucan fiber powder and vacuum-drying on cooking quality and physical properties of pasta. CYTA J. Food 2016, 14, 101-108. [CrossRef]

100. Piwińska, M.; Wyrwisz, J.; Wierzbicka, A. Effect of micronization of high-fiber oat powder and vacuum-drying on pasta quality. CYTA J. Food 2016, 14, 433-439. [CrossRef]

101. Padalino, L.; Conte, A.; Lecce, L.; Likyova, D.; Sicari, V.; Pellicanò, T.M.; Poiana, M.; Del Nobile, M.A. Functional pasta with tomato by-product as a source of antioxidant compounds and dietary fibre. Czech J. Food Sci. 2017, 35, 48-56.

102. Navarro-González, I.; García-Valverde, V.; García-Alonso, J.; Periago, M.J. Chemical profile, functional and antioxidant properties of tomato peel fiber. Food Res. Int. 2011, 44, 1528-1535. [CrossRef]

103. Marinelli, V.; Padalino, L.; Conte, A.; Del Nobile, M.A.; Briviba, K. Red grape marc flour as food ingredient in durum wheat spaghetti: Nutritional evaluation and bioaccessibility of bioactive compounds. Food Sci. Technol. Res. 2018, 24, 1093-1100. [CrossRef]

104. Llobera, A.; Cañellas, J. Dietary fibre content and antioxidant activity of Manto Negro red grape (Vitis vinifera): Pomace and stem. Food Chem. 2007, 101, 659-666. [CrossRef]

105. Cappa, C.; Cappa, C. Brewer's spent grain valorization in fiber-enriched fresh egg pasta production: Modelling and optimization study. LWT Food Sci. Technol. 2017, 82, 464-470. [CrossRef]

106. Nocente, F.; Taddei, F.; Galassi, E.; Gazza, L. Upcycling of brewers' spent grain by production of dry pasta with higher nutritional potential. LWT Food Sci. Technol. 2019, 114, 108421. [CrossRef]

107. Mussatto, S.I.; Dragone, G.; Roberto, I.C. Brewers' spent grain: Generation, characteristics and potential applications. J. Cereal Sci. 2006, 43, 1-14. [CrossRef]

108. Kim, B.R.; Kim, S.; Bae, G.S.; Chang, M.B.; Moon, B.K. Quality characteristics of common wheat fresh noodle with insoluble dietary fiber from kimchi by-product. LWT Food Sci. Technol. 2017, 85, 240-245. [CrossRef]

109. Park, K.Y.; Jeong, J.K.; Lee, Y.E.; Daily, J.W. Health benefits of kimchi (korean fermented vegetables) as a probiotic food. J. Med. Food 2014, 17, 6-20. [CrossRef] [PubMed]

110. Benítez, V.; Mollá, E.; Martín-Cabrejas, M.A.; Aguilera, Y.; López-Andréu, F.J.; Cools, K.; Terry, L.A.; Esteban, R.M. Characterization of Industrial Onion Wastes (Allium cepa L.): Dietary Fibre and Bioactive Compounds. Plant. Foods Hum. Nutr. 2011, 66, 48-57. [CrossRef]

111. Badaró, A.T.; Amigo, J.M.; Blasco, J.; Aleixos, N.; Ferreira, A.R.; Clerici, M.T.P.S.; Barbin, D.F. Near infrared hyperspectral imaging and spectral unmixing methods for evaluation of fiber distribution in enriched pasta. Food Chem. 2021, 343, 128517. [CrossRef] 